\title{
Neurofilaments and Neurofilament Proteins in Health and Disease
}

\author{
Aidong Yuan, ${ }^{1,2}$ Mala V. Rao, ${ }^{1,2}$ Veeranna, ${ }^{1,2}$ and Ralph A. Nixon ${ }^{1,2,3}$ \\ ${ }^{1}$ Center for Dementia Research, Nathan Kline Institute, Orangeburg, New York 10962 \\ ${ }^{2}$ Department of Psychiatry, New York University School of Medicine, New York, New York 10016 \\ ${ }^{3}$ Cell Biology, New York University School of Medicine, New York, New York 10016 \\ Correspondence: yuan@nki.rfmh.org, nixon@nki.rfmh.org
}

\section{SUMMARY}

Neurofilaments (NFs) are unique among tissue-specific classes of intermediate filaments (IFs) in being heteropolymers composed of four subunits (NF-L [neurofilament light]; NF-M [neurofilament middle]; NF-H [neurofilament heavy]; and $\alpha$-internexin or peripherin), each having different domain structures and functions. Here, we review how NFs provide structural support for the highly asymmetric geometries of neurons and, especially, for the marked radial expansion of myelinated axons crucial for effective nerve conduction velocity. NFs in axons extensively cross-bridge and interconnect with other non-IF components of the cytoskeleton, including microtubules, actin filaments, and other fibrous cytoskeletal elements, to establish a regionally specialized network that undergoes exceptionally slow local turnover and serves as a docking platform to organize other organelles and proteins. We also discuss how a small pool of oligomeric and short filamentous precursors in the slow phase of axonal transport maintains this network. A complex pattern of phosphorylation and dephosphorylation events on each subunit modulates filament assembly, turnover, and organization within the axonal cytoskeleton. Multiple factors, and especially turnover rate, determine the size of the network, which can vary substantially along the axon. NF gene mutations cause several neuroaxonal disorders characterized by disrupted subunit assembly and NF aggregation. Additional NFalterations are associated with varied neuropsychiatric disorders. New evidence that subunits of NFs exist within postsynaptic terminal boutons and influence neurotransmission suggests how NF proteins might contribute to normal synaptic function and neuropsychiatric disease states.

\section{Outline}
1 Introduction
2 Subunit composition of NFs
3 NF protein domain structure and assembly
4 NF protein expression
5 Posttranslational modifications of NF proteins
6 NF protein degradation
7 Axonal transport of NF proteins

8 Functions of NF proteins

9 NF subunit-interacting organelles and proteins

10 NF proteins in disease states

11 NF proteins as potential markers of disease and injury

12 NF biology - The next decade

References

Editors: Thomas D. Pollard and Robert D. Goldman

Additional Perspectives on The Cytoskeleton available at www.cshperspectives.org

Copyright $\odot 2017$ Cold Spring Harbor Laboratory Press; all rights reserved; doi: 10.1101/cshperspect.a018309 
A. Yuan et al.

\section{INTRODUCTION}

Neurofibrils in the cytoplasm of neurons were first visualized with silver stains a century ago by the neuroanatomists Ramón y Cajal, Golgi, and others, who also noted their striking abundance in axons. Decades later, electron microscopy analyses revealed that neurofibrils in axons are bundles of 10-nm-diameter filaments (Schmitt and Geren 1950), which were designated "neurofilaments" (NFs) based on their location exclusively in neurons. NFs are now known to be members of the family of intermediate filaments (IFs) defined as cell-selective or cell-specific 10$\mathrm{nm}$ filaments that are "intermediate" in diameter between actin filaments $(6 \mathrm{~nm})$ and myosin filaments $(15 \mathrm{~nm})$ found in muscle cells (Ishikawa et al. 1968). Six major classes of IF proteins are known: class I (acidic keratins), class II (basic keratins), class III (vimentin, desmin, peripherin, and glial fibrillary acidic protein [GFAP]), class IV (NF-L or neurofilament light, NF-M or neurofilament middle, NF-H or neurofilament heavy, $\alpha$-internexin), class $\mathrm{V}$ (nuclear lamins), and class VI (nestin) (Dahlstrand et al. 1992; Steinert et al. 1999; Michalczyk and Ziman 2005; Guerette et al. 2007) (for an introduction to IFs, see Herrmann and Aebi 2016).

NFs are relatively sparse and tortuous in dendrites and perikarya, whereas in axons they can be numerous, mainly straight and unbranched, and very long $(118 \mu \mathrm{m}$ on average) (Burton and Wentz 1992). The very abundant NFs in large myelinated axons are highly organized into parallel arrays, within which individual NFs are kept a minimum distance from each other by side arms that project perpendicularly from the filament core (Fig. 1). After axons establish synaptic contacts, signals from myelinating glia (Sanchez et al. 2000) induce many axons to expand radially as much as 10-fold, during which the NF number increases commensurately. Microtubules (MTs) can also proliferate in expanding axons, but, in the largest axons, NFs outnumber MTs by as much as an order of magnitude. Unlike most other IF systems (Schnapp and Reese 1982), NFs establish extensive cross-bridges with each other and with actin filaments and MTs through several types of cross-bridging proteins, including actin (Frappier et al. 1992), spectrin (Frappier et al. 1987, 1991), bullous pemphigoid antigen (BPAG) (Yang et al. 1996, 1999), plectin (Svitkina et al. 1996), and MT-associated proteins such as $\tau$ (Miyata et al. 1986) and MAP 1 and MAP 2 (Leterrier et al. 1982; Miyata et al. 1986; Frappier et al. 1991; Ma et al. 2000).

The size and composition of the cytoskeleton along large axons can be markedly nonuniform along their length. The abundance of NFs in the axonal cytoskeleton of peripheral nerves decreases more than twofold at more distal levels (Schlaepfer and Bruce 1990a), whereas the NF number in optic axons increases threefold proximally to distally (Nixon and Logvinenko 1986). Moreover, at specific local sites along axons, abrupt striking threefold to fourfold variations in NF number and phosphorylation state can be seen, such as at the junction between unmyelinated and myelinated portions of retinal ganglion cell axons (Nixon et al. 1994b), at initial segments of dorsal root axons, and at nodes of Ranvier (Fig. 2) (Hsieh et al. 1994). NFs within the node of Ranvier, for example, are fewer and more closely packed than in the adjacent myelinated internode of the same axon (Hsieh et al. 1994). Although signals from myelinating cells modulate local accumulation of NFs in axons, myelin itself does not regulate local NF density (Sanchez et al. 1996; Lunn et al. 2002).

The unique structure of NFs and their prominent involvement in the pathogenesis of multiple neurological diseases have long made NFs a focus of active research. In this review, we summarize the current understanding of NF structure and function in health and diseases and draw attention to important unanswered questions.

\section{SUBUNIT COMPOSITION OF NFs}

NFs are distinguished from other types of IFs by the complexity of their subunit structure and composition. The first neuronal IFs to be isolated were derived from bovine myelinated nerve fibers and initially assumed to have only one subunit of $58 \mathrm{kDa}$ (Shelanski et al. 1971), although these filaments were later shown to be predominantly glial filaments containing the class III IF GFAP as their major subunit. Studies of axonal transport in 1975 identified three proteins —of $\sim 200-, \sim 160-$, and $\sim 68$-kDa apparent molecular size by sodium dodecyl sulfate (SDS)polyacrylamide gel electrophoresis - that displayed identical patterns of slow translocation along axons ("slow component" of transport) under various conditions (Hoffman and Lasek 1975). Biochemical studies later confirmed the hypothesis that these proteins were subunits of NFs (NF-H, NF-M, and NF-L) (Liem et al. 1978; Schlaepfer and Freeman 1978) and identified an associated protein $-\alpha$-internexin - as an IF-binding protein (Pachter and Liem 1985). Recently, $\alpha$-internexin was shown to be the fourth subunit of NFs in the adult central nervous system (CNS) based on criteria used earlier to establish the other three subunits as NF components, including a characteristic pattern of axonal transport and subunit stoichiometry within 10-nm filaments, as well as new genetic criteria (Yuan et al. 2006b). Similar criteria applied to peripherin, another NF-associated protein selectively located in peripheral neurons (Portier et al. 1983; Parysek and Goldman 1987; Aletta et al. 1988), have established this protein as the fourth subunit of NFs in the adult peripheral nervous system (PNS) (Fig. 3) 

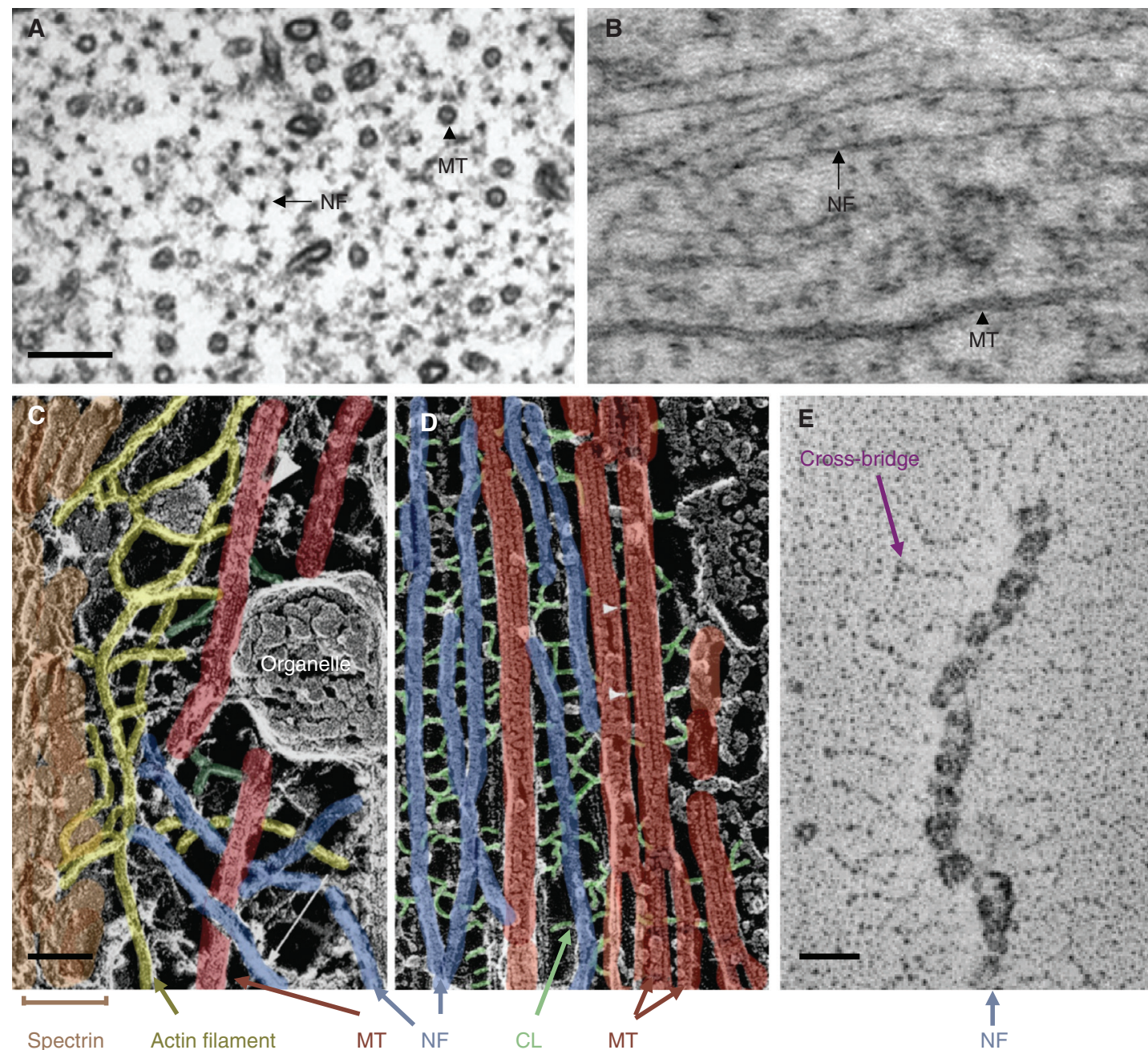

Figure 1. The neurofilament (NF) network in axons. Ultrastructural representation of NFs from mouse optic nerves in cross section $(A)$ and longitudinal section $(B)$. Arrows point to NFs, whereas arrowheads point to microtubules (MTs). Comparison of $A$ and $B$ illustrates bundles of parallel NFs and shows that individual NFs might be at a considerable distance from the nearest MT. Most NFs are regularly spaced from their neighbors as a result of the wispy projections of neurofilament middle (NF-M) and neurofilament heavy (NF-H) tails that emanate radially from the cores of some NFs in these mouse optic axons. These projections form cross-bridges between NFs, as visualized here in false-color images obtained by the quick-freeze deep-etching technique $(C, D)$ (adapted, with permission, from Hirokawa 1982). The core cytoskeleton of axons typically comprises parallel arrays of NFs and MTs interconnected by cross-linker (CL) elements $(D)$. Closer to the axolemma, the core cytoskeleton is cross-linked to the actin filament network and membrane skeleton by longer bridging elements $(C)$. (E) Electron micrograph of an isolated NF prepared by rotary shadowing. (Adapted, with permission from Elsevier, from Hisanaga and Hirokawa 1988.) Scale bars, $100 \mathrm{~nm}(A, B) ; 50 \mathrm{~nm}(C, D) ; 20 \mathrm{~nm}(E)$.

(Yuan et al. 2012b). Three additional IF proteins—nestin, vimentin, and synemin — are present mainly in developing neurons and nearly disappear as neurons in the brain mature postnatally and express increasing amounts of the four subunits of NF. The progressive replacement of class III IF (vimentin) and class III/VI (nestin) filaments by heteropolymeric assemblies of class IV NF subunits as neurons mature and establish synaptic contacts is part of a developmental program thought to convert a more plastic cytoskeleton into a more permanent and rigid structure (Nixon and Shea 1992). As the axon further matures, NF-L, NF-M, and $\alpha$-internexin assemblies gradually acquire more NF-H subunits, and the progressive phosphorylation of NF-H and NF-M side arms promotes formation of a highly stable axonal NF cytoskeleton (Nixon and Shea 1992) extensively cross-linked to other stationary elements of the core and membrane cytoskeleton. This organization of the axonal cytoskeleton provides structural support and docking sites for reversible interactions with vesicular organelles (Steiner et al. 1987; Wagner et al. 2003; Rao et al. 2011) and molec- 
A. Yuan et al.
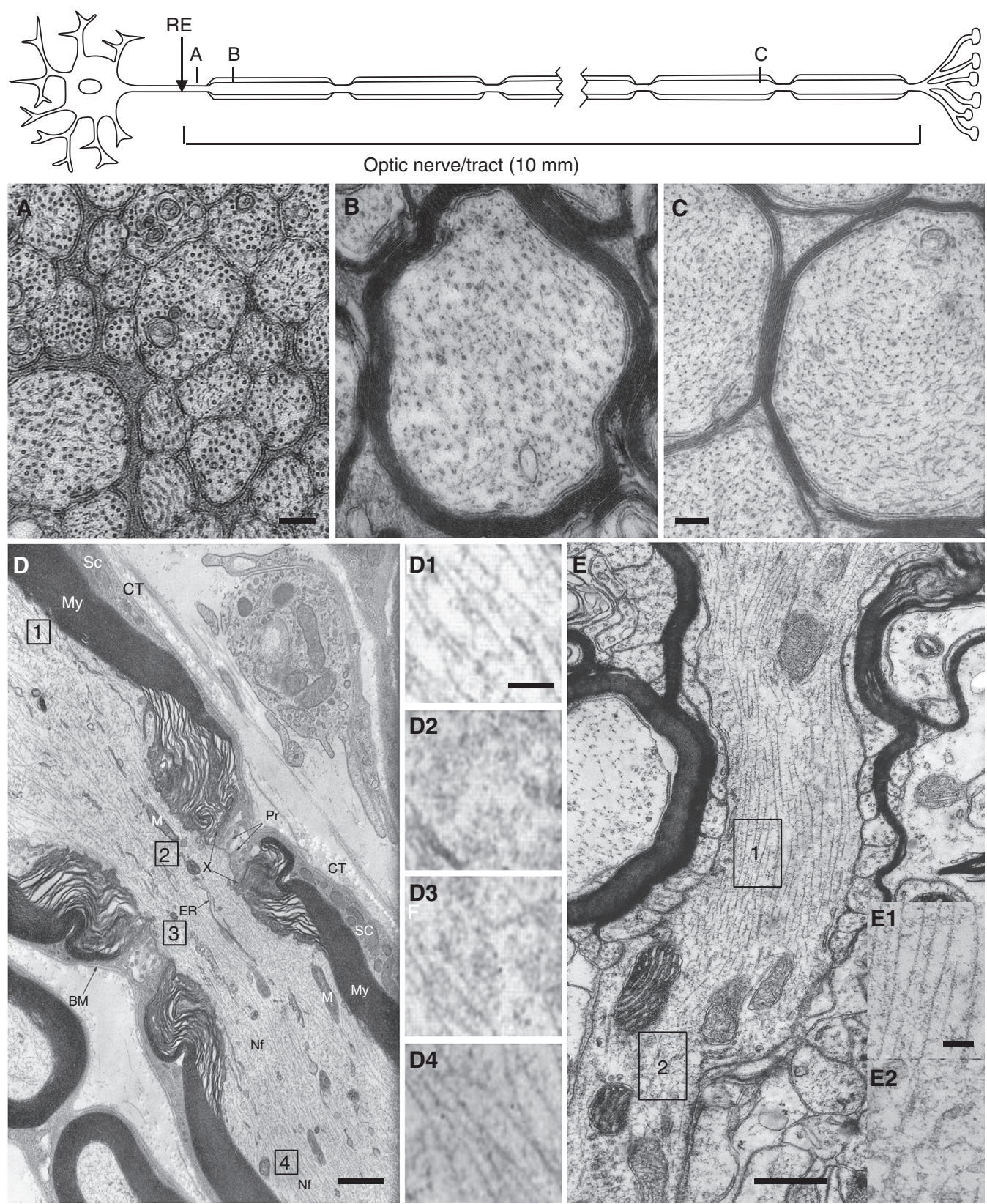

Figure 2. Nonuniform distribution of neurofilaments (NFs) along axons. (A-C) Electron micrographs of mouse optic axons magnified equally and viewed at three levels $-50 \mu \mathrm{m}(A), 2000 \mu \mathrm{m}(B)$, and $7000 \mu \mathrm{m}(C)$ from the eye-and summarized in cartoon form above. In these axons, NFs are sixfold more numerous distally than proximally. $(D)$ Electron micrograph of a node of Ranvier in the long section showing the node of Ranvier flanked by internodal segments insulated by layers of compact myelin (My). (Adapted from Porter and Bonneville 1973.) Enlarged images of myelinated ( 1 and 4 ) and unmyelinated regions (2 and 3) are displayed in insets (D1-D4). (E) An electron micrograph of a different node of Ranvier in the long section showing how the myelin sheath terminates through widening rims of myelin loops and the ensheathed axon becomes naked in the region of the node of Ranvier (adapted, with permission, from Spacek 2004). Insets (E1 and E2) are enlarged images of myelinated (1) and unmyelinated (2) regions. The cytoskeleton organization of unmyelinated portions of the optic axons and node of Ranvier is strikingly different from that of the myelinated portions just a short distance away, reflecting the influence of oligodendroglial or Schwann cell signaling on NF organization. RE, retinal excavation. Scale bars, $200 \mathrm{~nm}(A, B, C) ; 300 \mathrm{~nm}(D) ; 100 \mathrm{~nm}(D 1-D 4) ; 600 \mathrm{~nm}(E) ; 100 \mathrm{~nm}(E 1-E 2)$. 

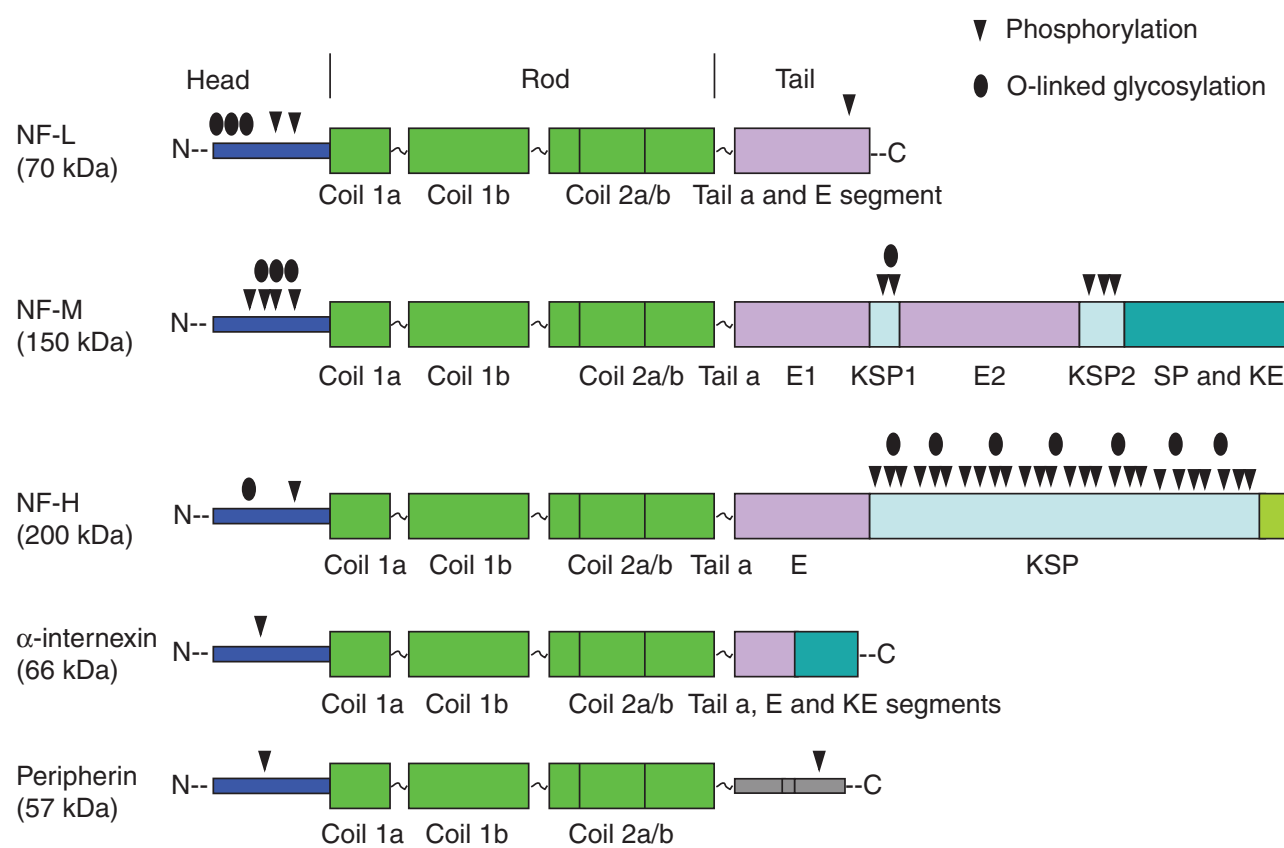

Figure 3. Domain structure and posttranslational modifications of neurofilament (NF) subunits. Neurofilament light (NF-L), neurofilament middle (NF-M), neurofilament heavy (NF-H), $\alpha$-internexin, and peripherin are the subunits of NFs in the mature nervous system. All NF subunits include a conserved $\alpha$-helical rod domain, comprising several coiled coils, and variable amino-terminal globular head regions and carboxy-terminal tail domains. NF-M and NF-H subunits are unique among intermediate filament (IF) proteins in having long carboxy-terminal domains with multiple lysine-serine-proline (KSP) repeats that are heavily phosphorylated. Phosphorylation and O-linked glycosylation sites on NF subunits are shown. E segment, glutamic-acid-rich segment; E1, glutamic-acidrich segment 1; E2, glutamic-acid-rich segment 2; KE, lysine-glutamic acid; KEP, lysine-glutamic acid-proline; SP, serine-proline; KSP, lysine-serine-proline.

ular motors (Yabe et al. 1999; Shah et al. 2000; Rao et al. 2002a; Xia et al. 2003).

The molecular masses of NF-H, NF-M, NF-L, $\alpha$-internexin, and peripherin predicted from the DNA sequences are $112.5,102.5,61.5,55.4$, and $53.7 \mathrm{kDa}$, respectively, in human and 117, 95.9, 61.5, 55.4, and $54.3 \mathrm{kDa}$, respectively, in mouse. These subunits migrate anomalously on SDScontaining gels because of an abundance of negatively charged amino acids (glutamic acids) in their sequences and posttranslational modifications such as phosphorylation and glycosylation. The commonly reported molecular masses on SDS-PAGE (polyacrylamide gel electrophoresis) are $200-220,145-160,68-70,58-66$, and $57-59 \mathrm{kDa}$ for NF-H, NF-M, NF-L, $\alpha$-internexin, and peripherin, respectively.

\section{NF PROTEIN DOMAIN STRUCTURE AND ASSEMBLY}

All NF subunits have a tripartite structure: a conserved central $\alpha$-helical rod region $(\sim 310$ amino acids), a short variable head domain at the amino-terminal end $(\sim 98$ amino acids), and a tail of highly variable length at the carboxy-terminal end (63-618 amino acids) (Fig. 3). The short head domain is rich in serine and threonine residues and contains consensus sites for O-linked glycosylation or phosphorylation. The central rod domain, shared with other members of the IF family, contains long stretches of hydrophobic heptad repeats, which favor the formation of $\alpha$-helical coiled-coil dimers. The carboxy-terminal domains differ substantially in the lengths of long glutamicand lysine-rich stretches, which mainly determine the sizes of the four NF subunits. Peripherin has a short tail that includes a single phosphotyrosine residue (Angelastro et al. 1998). The NF-L tail is also short and contains many glutamic acid residues (an "E segment"), whereas the NF-M and NF-H tails are much longer and contain multiple E segments. There are six to 15 repeats of a Lys-Ser-Pro ("KSP") motif in the tail domain of NF-M, depending on the mammalian species, whereas the number of KSP repeats in NF-H ranges from 40 to 51 (Fig. 3). NF-H and NF-M also have one or a few shorter "SP" motifs lacking an amino-terminally adjacent lysine.

On their own, NF-M and NF-H appear to be assembly incompetent, but NF-L, peripherin, and $\alpha$-internexin can form $10-\mathrm{nm}$ homopolymeric filaments in vitro and hetero- 
A. Yuan et al.

polymers with other NF subunits (Yuan et al. 2006b, $2012 b$ ). The subunit stoichiometry of NFs can vary in different neuronal populations and during the period of neuronal development-the four NF subunits NF-L, NF-M, $\mathrm{NF}-\mathrm{H}$, and $\alpha$-internexin invariably compose CNS NFs, whereas peripherin, NF-L, NF-M, and NF-H compose NFs in the PNS (Yuan et al. 2006b, 2012b). The backbone of the filament is mainly formed by NF-L, plus peripherin or $\alpha$-internexin, whereas NF-M and NF-H associate more peripherally (Leermakers and Zhulina 2010). The two largest subunits-NF-M and NF-H-are distinguished from the other NF subunits, and other IF proteins, by the exceptional lengths of their tail domains (Geisler et al. 1983; Franke 1987; Steinert and Roop 1988; Shaw 1991). These tail domains are localized peripherally along the filament core (Fig. 1) (Willard and Simon 1981; Sharp et al. 1982) and, especially when extensively phosphorylated, these domains project radially from the filament core to form side arms that maintain a minimal spacing between individual NFs and between NFs and MTs (Pant et al. 1978; Leterrier et al. 1982; Liem and Hutchison 1982; Julien and Mushynski 1983; Hirokawa et al. 1984; Nakagawa et al. 1995; Chen et al. 2000; Rao et al. 2002b, 2003). Finally, recent evidence indicates that $\alpha$-internexin fine-tunes the NF network through increasing interfilament spacing (Kornreich et al. 2015).

Assembly of NF subunits into NFs does not require nucleotide binding or hydrolysis but is strongly dependent on ionic strength, $\mathrm{pH}$, and temperature (Angelides et al. 1989). The formation of NFs, like that of other IFs, is believed to begin when two monomers associate into polar coiled-coil dimers (45-50 $\mathrm{nm}$ in length), which is the basic and essential building block of NFs (Fig. 4). The mechanism that specifies heterodimeric interaction among NF proteins is believed to reside in the tail domains (Carpenter and Ip 1996). Two dimers then form staggered antiparallel tetramers. As a result of this antiparallel arrangement, NFs lack polarity, unlike the polar structure of MTs and actin filaments, which have two distinct ends. The lateral association of eight tetramers (a total of 32 monomers) results in the formation of cylindrical structures known as unitlength filaments (ULFs), with an approximate diameter of $16 \mathrm{~nm}$. Gradual end-to-end annealing of these ULFs in the longitudinal direction results in filament elongation, which is followed by radial compaction to ultimately achieve the final long NF of diameter $10 \mathrm{~nm}$ (Fig. 4) (Fuchs and Weber 1994; Herrmann and Aebi 2004; Herrmann et al. 2007; Goldman et al. 2008) (for further assembly details, see Herrmann and Aebi 2016).

\section{NF PROTEIN EXPRESSION}

The NF-M subunit exists in all vertebrates, and all other NF proteins are believed to have originated by gene duplication from an ancestral NF-M-like protein. The most primitive

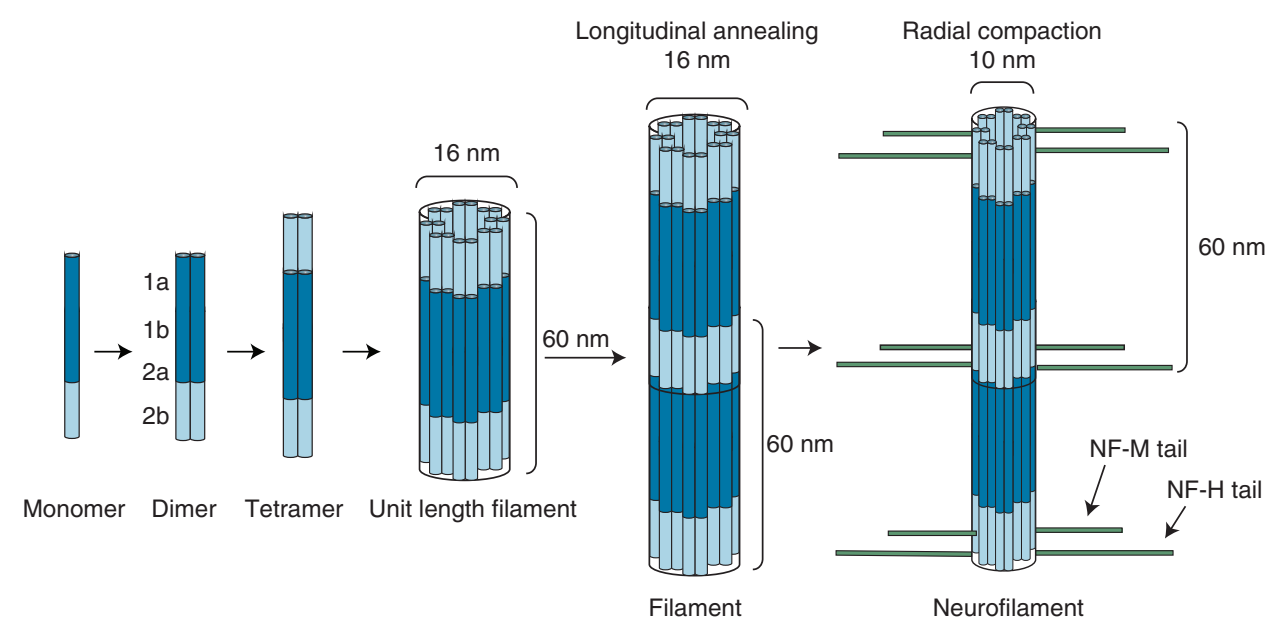

Figure 4. Neurofilament (NF) assembly. Different monomers of NFs form parallel coiled-coil heterodimers between subunit core domains. Two dimers then form staggered antiparallel tetramers through interactions between coil domains 1a, 1b, and 2a (for further details, see Herrmann and Aebi 2016). The lateral association of eight tetramers results in the formation of cylindrical structures known as unit-length filaments (ULFs), with an approximate diameter of $16 \mathrm{~nm}$ and length of $60 \mathrm{~nm}$. Gradual end-to-end annealing of these ULFs in the longitudinal direction results in filament elongation, which is followed by radial compaction to ultimately achieve the mature long NF polymer of diameter $10 \mathrm{~nm}$. Tail domains of neurofilament middle (NF-M) and neurofilament heavy (NF-H) radiate outward from the filament core because of the extensive negative charges arising from large numbers of glutamic acid and phosphorylated serine and threonine residues. Tail repulsion is not driven by the phosphorylation of the head domain of NF-H and NF-M. 
living vertebrate is the lamprey, which has only a single NFM-like subunit (NF-180) (Hall et al. 2000), but more-recent studies suggest that this subunit might need other NF proteins for filament assembly (Jin et al. 2011). In tiger salamander olfactory axons, NF-M is abundant, but NF-L and NF-H subunits are present at trace levels, resulting in formation of only rare NFs (Burton and Wentz 1992). The molecular subunit composition of NFs progressively changes during axon development. In the developing Xenopus laevis spinal cord, peripherin emerges at the earliest stages of neurite outgrowth. NF-M and $\alpha$-internexin (or $\alpha$ internexin-like Xenopus protein) appear later, as axons continue to elongate, and NF-L is expressed after axons contact muscle (Undamatla and Szaro 2001). In developing mouse myenteric neurons, peripherin, $\alpha$-internexin, and NF-M emerge simultaneously before the appearance of NF-L and NF-H subunits, indicating a close relationship among peripherin, $\alpha$-internexin, and NF-M (FaussonePellegrini et al. 1999). The expression of NF-H during postnatal development is delayed compared with that of NF-L and NF-M (Shaw and Weber 1982; Pachter and Liem 1984; Carden et al. 1987; Schlaepfer and Bruce 1990b; Giasson and Mushynski 1997a). Reduced NF expression is a general response to axonal injury in both PNS and CNS axons (Hoffman and Cleveland 1988; Hoffman et al. 1993). In normal regenerating axons, NF subunits reemerge in a temporal sequence reminiscent of that in developing neurons (Zhao and Szaro 1995).

\section{POSTTRANSLATIONAL MODIFICATIONS OF NF PROTEINS}

NF proteins are modified, after they are translated, by attachment of phosphate and $\mathrm{O}$-linked $\mathrm{N}$-acetylglucosamine (O-GlcNAc) to individual serine and threonine residues. In addition to these well-established modifications, NFs can also be modified to some extent by nitration, oxidation, and ubiquitination. NFs are among the most highly phosphorylated proteins in brain tissue. The phosphorylation status of NFs depends on a complex regulation between NF kinases and phosphatases (Nixon and Sihag 1991). All subunits are phosphorylated at their amino-terminal head domain, whereas only the high-molecular-mass subunits (NF-H and NF-M) are extensively phosphorylated along their carboxy-terminal tail domains (Fig. 3) (Nixon and Sihag 1991; Pant and Veeranna 1995; Sihag et al. 2007). NF head-domain phosphorylation occurs in the cell body, and phosphate turnover on this domain is relatively dynamic as NFs enter the axon (Sihag and Nixon 1991), suggesting roles in regulating initial events in NF subunit behavior. The more extensive phosphorylation of NF-M and NF-H tail domains is delayed until newly formed NF assemblies have translocated into axons, and many of these added phosphate groups are slowly turned over (Nixon et al. 1994a, 1994b). Subunit phosphorylation is mediated mainly by second-messenger-dependent protein kinases (Nixon and Sihag 1991; Pant and Veeranna 1995; Grant and Pant 2000; Sihag et al. 2007) and is, therefore, subject to modulation by a vast array of second-messenger signals (McKnight 1991; Perrot et al. 2008).

Phosphorylation mediated by protein kinase A (PKA), protein kinase $\mathrm{C}$ (PKC), and calcium/calmodulin-dependent protein kinase type II (CAMK II) acting along the head domain plays a key role in regulating the assembly of NFs. Both PKA and PKC are able to phosphorylate NF-L at serine 55 and serine 23 (Sihag and Nixon 1991; Sihag et al. 1999), and a proline-directed threonine (Thr21) is phosphorylated by cyclin-dependent kinase 5 (cdk5), mitogen-activated protein kinase 3 (Erk1), and mitogen-activated protein kinase 1 (Erk2) (Sasaki et al. 2006). Serine residues 12, 27, 33, and 51 on NF-L phosphorylated by PKC promote disassembly (Gonda et al. 1990; Giasson et al. 1996). Similar proline-directed phosphorylation sites exist in the NF-M head, and PKA is implicated for at least one of these sites (serine 23) (Sihag et al. 1999). It is less clear, however, why there are more head-domain phosphorylation sites on NF-M than on other subunits, and what functions are served by the complex changes in phosphate topography on the NF-M head domain occurring as NF subunits are transported and phosphates are removed from certain sites (Sihag and Nixon 1991). Phosphorylation of the peripherin head domain induces filament fragmentation (Giasson and Mushynski 1998) and, in pheochromocytoma PC12 cells, is enhanced by nerve growth factor (NGF)-induced activation of PKA and PKC (Aletta et al. 1989). Similarly, phosphorylation of the $\alpha$ internexin head domain by PKA influences its assembly and disassembly (Giasson and Mushynski 1998). Collectively, these findings point to assembly/disassembly being the major function of head phosphorylation. They also suggest that it is important to regulate the timing of subunit assembly to prevent pathological aggregation of NFs within the cell body, which disrupts their export into axons. Consistent with this idea, NF head domain phosphorylation also prevents phosphorylation of the tail domain within the cell body (Zheng et al. 2003). Beyond these roles, phosphorylation of the head domain of NF-L and NF-M alters the interactions of NFs with protein ligands, including protein 14-3-3 (Miao et al. 2013), the secretory regulator synapsin (Steiner et al. 1987), and brain spectrin (Frappier et al. 1987) and, not surprisingly, influences neurite outgrowth (Kesavapany et al. 2003).

The carboxy-terminal tail domains of NFs are phosphorylated on their entry into and transit along the axon 
A. Yuan et al.

(Nixon and Sihag 1991). Most of this phosphorylation occurs at the KSP motif and the related smaller serine/ threonine KSP repeats that vary in number across mammalian species (Barry et al. 2010). Human and mouse NF$\mathrm{H}$ have 45 and 51 KSP repeats, respectively (Kesavapany et al. 2003). There are two major types of KSP repeats in the NF tail domain, KSPXK and KSPXXXP, in which X represents any amino acid.

The KSPXK type is the majority in human NF-H, whereas the KSPXXXK sequence comprises the majority of KSP motifs in rodents. This distinction is important because of the specificities of the protein kinases that regulate phosphorylation of these two motifs-cyclin-dependent kinases (CDKs) phosphorylate only KSPXK sites, and mitogen-activated protein kinases (MAPKs) preferentially phosphorylate KSPXXXK sites (Shetty et al. 1993; Veeranna et al. 1998; Kesavapany et al. 2003). The state of phosphorylation of the tail domains increases proximodistally along axons (Nixon et al. 1987), and rates of phosphate turnover on the different subunits vary along the axon (Nixon and Lewis 1986). The proline-directed kinases, CDKs, extracellular signal-regulated kinases (ERKs), Jun amino-terminal kinases (JNKs), p38 kinases, and glycogen synthase kinase 3 (GSK3) phosphorylate the tail domain of NFs (Sihag et al. 2007), and these kinases are influenced by signaling cascades responsive to stress, neurotransmitters, growth factors, and other receptor-mediated signaling alterations. The cross talk among kinases, and between kinases and phosphatases, is also important in regulating NF tail domain phosphorylation (Veeranna et al. 2011). Interestingly, myelination and synaptogenesis influence tail domain phosphorylation (de Waegh et al. 1992; Sanchez et al. 2000). As synaptic connections are established, bidirectional signaling from myelinating glial cells (Sanchez et al. 1996, 2000) initiates a marked radial expansion of axons supported by commensurate accumulation of NFs in axons, which is accompanied and possibly mediated by the increased phosphorylation of NF-M and NF-H tail domains (Sherman et al. 2012). Phosphates turn over while NFs are in the cell body and during their entry and transit along the axon, and only some of them are replaced by new phosphates, suggesting that the topography of phosphates on NFs changes in relation to functions served in different domains of the neuron (Nixon and Lewis 1986; Saito et al. 1995).

Less is known about NF phosphatases. The phosphatases associated with NFs dephosphorylate NF-H, causing a shift in its electrophoretic mobility, which might imply a change in conformation (Guru et al. 1991). The observation that okadaic acid, an inhibitor of protein phosphatases PP2A and PP1, enhances NF phosphorylation in the cell body and neurites suggested that these phosphatases are involved in regulating NF phosphorylation in several neu- ronal cell types (Hall and Kosik 1993; Giasson et al. 1996). PP2A dephosphorylates cdk5 sites in NF-H (Veeranna et al. 1995). PP2A and PP1 associate with enriched preparations of NFs from bovine brain, and PP2A was implicated as the major phosphatase for NFs in this in vitro preparation, with PP1 playing a lesser role (Strack et al. 1997). Although the activity of NF kinases decreases during maturation and aging (Veeranna et al. 2011), this is more than offset as NF tail domains actually become progressively more phosphorylated over time, mainly because of the decreasing activities of protein phosphatases PP2A and PP1 (Veeranna et al. 2011).

\section{NF PROTEIN DEGRADATION}

NF proteins are substrates of multiple proteolytic systems, including calpains, the proteasome, and autophagy (Nixon and Marotta 1984; Hollenbeck and Bray 1987; Suzuki et al. 1988; Shaw et al. 2004; Song et al. 2012)—although the contributions of each system to turnover in different regions of the neuron under physiological conditions or in disease states are poorly understood. NF assembly confers significant proteolytic resistance to NF subunits because deletion of three NF subunits leads to degradation of the fourth subunit (Yuan et al. 2015c). Moreover, multiple in vivo pulse-labeling studies indicate that NFs are extraordinarily stable in axons (half-life of $\sim 55 \mathrm{~d}$ ) (Nixon and Logvinenko 1986; Yuan et al. 2009; Rao et al. 2012). By an independent method, Julien and colleagues also showed that NFs have extremely long half-lives in axons in vivo (Millecamps et al. 2007). In that study, NF-L expression in a conditional NF-L knockout mouse was acutely shut off and the fate of the preexisting NFs was monitored. Preexisting NFs in the axon remained stationary and displayed exceptionally slow turnover. The observed half-lives of between 4.5 and 8 mo are much longer than would be predicted by a loss through slow axonal transport.

NF-H and NF-M subunits are highly sensitive to proteases once they are dephosphorylated (Pant 1988), suggesting that phosphate groups on these subunits confer resistance to protease cleavage and, hence, stability to the $\mathrm{NF}$ cytoskeleton in axons. Indeed, eliminating the NF-H and NF-M tails substantially reduces stability of the NF cytoskeleton in vivo and increases the degradation of NF$\mathrm{L}$ and the truncated, tailless NF-M and NF-H subunits (Rao et al. 2012). These data suggest that carboxy-terminal tails of NF-H and NF-M together impart stability to NFs.

It was earlier believed that NFs must be mainly degraded at the synapse if it is assumed that they are moving continuously in bulk into the nerve terminals by axonal transport (Roots 1983), although the metabolic burden on neurons, especially within the presynaptic terminal, 
would need to be enormous in this scenario. Instead, later evidence that the NF network is stationary and turns over very slowly (Nixon 1998; Millecamps et al. 2007) explains how a large NF population in mature axons can be maintained by a small population of transported precursors at a much smaller cost of energy. Finally, the even smaller proportion of NF proteins that undergoes axonal transport but is not incorporated into the axonal cytoskeleton might ultimately reach the presynaptic terminal and be degraded at this site (Roots 1983; Hoffman et al. 1992).

\section{AXONAL TRANSPORT OF NF PROTEINS}

Axonal transport comprises both anterograde and retrograde traffic, the components of which can be subclassified into fast or slowly transported cargoes. NF proteins, as well as MT proteins, are transported in the slow transport component, which carries at varying slow velocities a wide assortment of nonvesicular protein cargoes. Membranous organelles are the main constituents of the fast transport component, and although the molecular mechanisms underlying their transport have become increasingly clear (Hirokawa et al. 2010; Zala et al. 2013), those regulating the slow transport of cytoskeletal and associated proteins have been more elusive, despite significant recent progress.

\subsection{The Transport Forms of NF Proteins}

Because methods were initially not available to visualize NF subunits or manipulate their levels individually, the assembly state of NF proteins during axonal transport was a subject of much debate during the 1980s and 1990s (Baas and Brown 1997; Hirokawa et al. 1997; Nixon 1998). With the application of newer in vivo genetic approaches and live-cell imaging techniques, evidence now supports both sides of the original controversy over whether NFs are translocated as assembled polymers or as individual subunits and oligomers. On the one hand, live-cell imaging methods revealed movements of individual short NFs (1.0-15.8 $\mu \mathrm{m}$ in length) along the relatively NF-poor growing axons of developing neurons transfected with green fluorescent protein (GFP)-labeled NF subunits (Roy et al. 2000; Wang et al. 2000; Yuan et al. 2009). On the other, fluorescent puncta representing nonfilamentous assemblies of GFP-labeled NF subunits (Yabe et al. 1999; Prahlad et al. 2000) have been observed in axons. Moreover, in vivo analyses of transport along myelinated axons of adult mice in which single or multiple NF genes are deleted showed that formation of complete NFs is not a requirement for the transport of NF subunits (Yuan et al. 2003, 2006b). These analyses established that the minimum requirement for NF transport is a heterodimer containing either NF-M or $\alpha$-internexin as obligatory subunits (Yuan et al. 2003).

Seemingly conflicting observations about the assembly state of transported NF subunits have been reconciled by photobleaching analyses of GFP-tagged NF-L in cultured primary neurons, which showed transport of both nonfilamentous NF subunit assemblies and short NF polymers in the same axon (Yuan et al. 2009). At proximal axon levels, nonfilamentous NF subunit assemblies are transported, whereas at distal levels of the same axon, predominantly short NFs are observed in transit. Collectively, the observations show that NF proteins exist in multiple assembly forms during axonal transport and suggest that nonfilamentous heterooligomers assemble into filaments as they are transported (Yuan et al. 2009). At a critical level of NF expression in these growing neurons, transported NF assemblies and short NFs establish a stationary network beginning at proximal axonal levels. Once axons have fully matured, in vivo pulse-radiolabeling studies have shown that NFs along the entire axonal length have been integrated into a stationary cytoskeletal network (Nixon and Logvinenko 1986). It is possible that NFs elongate within this structure, given that end-to-end annealing of short NFs to longer NFs has been seen in mouse cortical neurons in culture (Uchida et al. 2013).

\subsection{Motors Mediating NF Protein Transport}

The principal motor protein superfamilies (Miki et al. 2001; Brown and Bridgman 2004)—MT-based kinesins and dynein, and actin filament-based myosins - have often been considered candidate motors for the translocation of NFs at slow rates (Prahlad et al. 2000; Alami et al. 2009; Sunil et al. 2012). Kinesin-I has been proposed as an anterograde motor for NF based on its reported interactions with NF-H or NF-M subunits (Yabe et al. 2000; Jung et al. 2005) and on the inhibitory effect of antibodies against kinesin-I on NF transport (Yabe et al. 1999). NF-H is dispensable for NF transport (Rao et al. 2002b; Yuan et al. 2006b), however, implying that if kinesin-I is an NF motor, a different NF subunit is likely the mediator of this transport. Although this issue is not yet resolved, additional investigations in mice lacking kinesin-I A (an isoform of kinesin-I) (Xia et al. 2003) or in cultured neurons expressing mutant kinesin-I (Wang and Brown 2010) have supported the earlier findings. Because kinesin-I transports many different cargoes, including synaptic vesicles, synaptic membranes, mitochondria, lysosomes, and tubulin dimers (Hirokawa et al. 2010), it is conceivable that the NF transport and distribution changes are secondary effects arising from interference with the role of kinesin-I with respect to these other cargoes. 
A. Yuan et al.

The dynein-dynactin complex is believed to be the motor mechanism for retrograde transport of NFs based on evidence that dynein interacts directly with the rod domain of the NF-M subunit in yeast two-hybrid assays (Wagner et al. 2004) and the dynein-dynactin complex copurifies with NFs (Shah et al. 2000). Also consistent with this notion, knockdown of dynein heavy chain expression using small interfering RNA (siRNA) significantly decreases retrograde NF transport (He et al. 2005; Uchida et al. 2009).

Myosin Va binds directly to NF-L, transports together with NFs in the slow phase of axonal transport, and influences the organization and density of NFs in axons (Rao et al. 2002b). Further transport analyses have suggested that myosin Va might support short-range NF movement by decreasing the duration of NF pauses (Jung et al. 2004; Francis et al. 2005; Alami et al. 2009). Despite these advances, interactions between candidate motors and NFs have not yet been fully characterized in live-cell imaging and in vivo studies, and important aspects of the molecular mechanisms regulating NF motility are still not well understood.

One model of transport posits that slow and fast rates are determined by differences in the amount of time the cargo spends pausing rather than by differences in transport velocity (Brown 2000; Li et al. 2012). In this model, the slow rate of NF transport would reflect long pauses alternating with rapid movement at a single velocity (Wang et al. 2000). However, an alternative view coming from computational modeling by Mitchell and Lee suggests that a single motor can carry an NF and that no cooperativity is required to produce the slow-transport velocity profile (Mitchell and Lee 2009). In contrast, cooperativity is required to produce the experimental velocity profiles for fast transport (Mitchell and Lee 2009), consistent with evidence that the average velocity of gliding MTs can transition from slow to fast, depending on the number of active motors engaged (Scharrel et al. 2014), and that larger organelle cargoes require multiple motors for fast transport (Kural et al. 2005). The enrichment of kinesin in fast axonal transport is consistent with the computational modeling of Mitchell and Lee (Elluru et al. 1995). Further investigation is therefore needed to address whether a single motor can explain both slow and fast anterograde NF transport or whether multiple motors, rather than a "fast motor," are required to support the velocities of cargoes in fast transport.

\subsection{Formation and Maintenance of the Axonal Cytoskeleton by Transported NF Precursors}

Both in vitro (Trivedi et al. 2007; Yuan et al. 2009) and in vivo studies (Nixon and Logvinenko 1986; Millecamps et al. 2007) have documented the existence of two populations of NFs-one undergoing slow-phase transport and a second stationary population comprising the NF network distributed nonuniformly along axons in patterns. Formation of the stable NF network, which has been visualized by time-lapse imaging of cultured neurons, is triggered in axons when NF expression reaches a critical threshold (Yuan et al. 2009), as occurs during normal brain development in vivo (Nixon and Shea 1992). In vivo pulse-labeling studies have shown that once newly synthesized NF proteins incorporate into the NF network, their distribution does not change for many months, even as the cytoskeletal network is very slowly turned over within the axon (Nixon and Logvinenko 1986; Nixon 1998; Millecamps et al. 2007) at a rate much slower than can be explained by the anterograde axonal transport velocity of NFs (Hoffman and Lasek 1975). For example, in conditional NF-L gene knockout mice, a third of the NF-L subunits are still present in axons 8 months after NF-L synthesis is shut off (Millecamps et al. 2007). These and other observations on mature neurons have shown that newly synthesized NF proteins undergoing transport are a small population compared with the size of the stationary population (Fig. 5) and, thus, correspond to the pool of precursors that maintains the large stable NF network along axons (Nixon and Logvinenko 1986; Hirokawa 1993; Yuan et al. 2009). Consistent with this concept, the transport rates and abundance of newly synthesized NF proteins are not invariable predictors of axonal NF content and radial growth, as proposed previously (Hoffman et al. 1984, 1985). For example, optic axons of mice lacking NF-L and NF-H have 90\% fewer NFs and greatly reduced axon calibers, yet NF-M is transported at normal slow transport rates. Moreover, in mice lacking the carboxy-terminal tail domains of both NF-M and NF-H, NF number is reduced sixfold proximally and threefold distally along optic axons, but the rate of NF transport is unaltered (Rao et al. 2012). The minimal impact of NF transport rate on steady-state NF content in axons strongly implies that NF precursors undergoing transport comprise only a small pool in axons. Recent evidence suggests that axonal NF content can be dissociated from NF transport rate and indicates that the rate of incorporation of transported NF precursors into the metabolically stable cytoskeletal network is the major determinant of axonal NF content, enabling the generation of the striking local variations in NF number seen along axons (Yuan et al. 2015a).

The formation of a stationary NF cytoskeleton allows neurons, especially those with long axons, to conserve energy while maintaining a large NF network that can constitute as much as $15 \%$ of the total protein content of peripheral nerves (Yuan et al. 2012b). The local regulation 


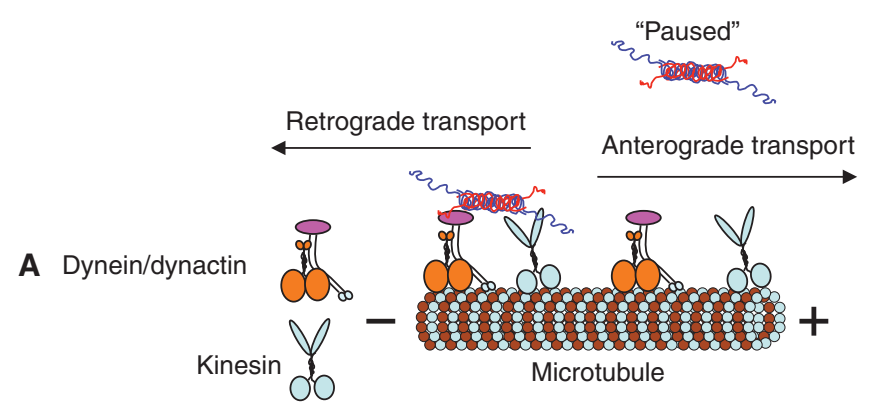

Cross-linker $\oint$

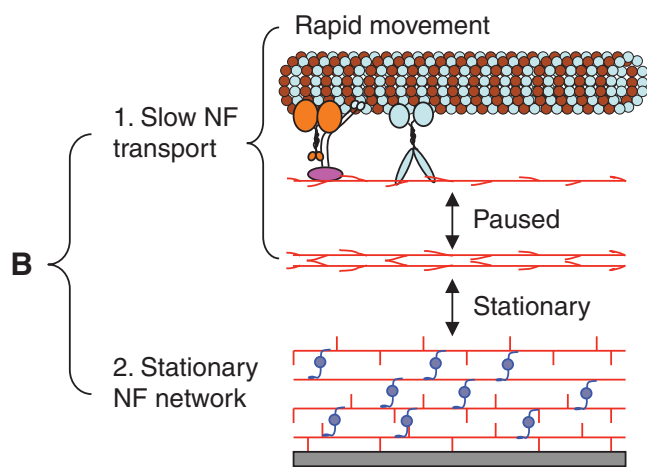

Figure 5. Formation of the axonal neurofilament (NF) network. $(A)$ Transport of short NFs or NF heterooligomers (Yuan et al. 2003, 2009) by molecular motors (Prahlad et al. 2000; Shah et al. 2000) is bidirectional. Here, an NF assembly is depicted moving in the retrograde direction (toward the "minus end") along a microtubule (MT), driven by dynein/dynactin. Another NF assembly is paused and was dissociated from kinesin in the anterograde direction (toward the "plus end"). (B) (1) Slow transport of NF proteins is the net rate achieved from the many intermittent, rapid motor-driven movements accompanied by "pauses," possibly reflecting the reversible attachment of NFs (long filament with side arms) to a molecular motor moving on an MT. (2) Stationary NF networks can arise by a process in which NFs are prevented from reattaching to the available molecular motors, presumably through interactions with stationary axonal structures (e.g., MTs and the membrane skeleton), indicated by cross-linking proteins (e.g., BPAG [bullous pemphigoid antigen] and plectin).

of the rates of incorporation of NF precursors into the NF network (Lewis and Nixon 1988; Sanchez et al. 2000) enables the neuron to control the size of the NF cytoskeleton regionally along the axon in response to myelinating cells and other needs. An earlier proposal of NF transport, originally advanced by Lasek and colleagues (Lasek 1986), envisioned axons as containing a single population of NFs continuously moving within the slow phase of axonal transport and degraded as the wavefront reaches the synaptic terminal (Li et al. 2012). The model, however, did not explain features of the axonal cytoskeleton that are now well established, including the striking variation of NF content and discrete regional specialization of the cytoskeleton along axons (Fig. 2), extensive cross-linking among ele- ments comprising the axonal cytoskeleton, the changing phosphate topography on NFs during transport, and the exceptionally long half-lives of axonal NF proteins. Moreover, given that motors carrying NFs probably move on MTs, translocation of the large bundles of extremely long NFs that are often not in proximity to a MT is challenging to explain. Beyond the energy required to power a continuous movement of the entire cytoskeleton, the large proteolytic capacity and energy that would be needed within presynaptic terminals to turn over all NF proteins entering this compartment are not well substantiated by current experimental evidence.

\subsection{Phosphorylation of NF Proteins and Axonal Transport}

A role for phosphorylation in the dynamic behaviors of NFs was first raised by observations that the average rate of bulk NF transport slows significantly when the NF-H subunit appears in abundance during axon maturation (Willard and Simon 1983) and becomes highly phosphorylated (Carden et al. 1987; Giasson and Mushynski 1997b; Veeranna et al. 1998). The carboxy-terminal regions of NF-H and NF-M protrude laterally from the filament backbone when phosphorylated to increase negative charges, and phosphorylation-dependent interactions of NFs with each other and with other cytoskeletal structures are thought to regulate formation of a cytoskeletal lattice that provides stability to mature axons (Grant and Pant 2000). Consistent with this relationship, overexpression of NF-H decreases NF transport rates in sciatic nerves in vivo (Collard et al. 1995; Marszalek et al. 1996), whereas NF-H deletion increases these rates (Zhu et al. 1998). Moreover, in cultured primary neurons in vitro, highly phosphorylated forms of NF-H are translocated more slowly than hypophosphorylated species (Jung et al. 2000a, 2000b), and NF transport accelerates when the phosphorylation state of overexpressed NF-H is lowered by mutagenesis of the KSP repeats (Ackerley et al. 2003). Thus, repetitive phosphorylation of the tails of NF-H and NF-M subunits is a predictable mechanism to regulate the NF transport rate. However, in vivo NF transport rates along optic axons are not altered in NF-H-null mice (Rao et al. 2002b). Similarly, abolishing tail domain phosphorylation on NF-H (Rao et al. 2002b; Yuan et al. 2006a) or from both NF-H and NF-M by eliminating the extensively phosphorylated carboxy-terminal tail domains of these subunits in mice does not alter NF transport rates in vivo (Rao et al. 2012). Taken together, these results suggest that, normally, NF-M and NF-H carboxy-terminal domain phosphorylation is not a key determinant of the NF transport rate. The current findings, however, are compatible with the possibility that abnormal states of NF-M and NF-H tail phos- 
A. Yuan et al.

phorylation achieved by subunit overexpression, mutagenesis, or disease states could slow NF transport and influence disease pathogenesis.

\section{FUNCTIONS OF NF PROTEINS}

\subsection{NFs in Axon Radial Growth and Nerve Conduction}

NFs are essential for the radial growth and structural stability of myelinated axons and for achieving the optimal propagation speed (conduction velocity) of electrical impulses along axons (Friede and Samorajski 1970; Ohara et al. 1993; Eyer and Peterson 1994; Zhu et al. 1997; Yum et al. 2009). Loss of NFs from axons of the Japanese quail due to nonsense mutation of NF-L and from mice lacking NF-L severely inhibits axon radial growth and nerve conduction velocities (Sakaguchi et al. 1993; Zhu et al. 1997) and in the mouse model reduces regenerative properties of adult peripheral axons (Zhu et al. 1997). NF content in axons supports increased conduction velocity in large myelinated fibers by expanding axon caliber and modulating ion channels (Kriz et al. 2000). In spite of their preserved caliber, large myelinated axons in NF-H knockout mice showed a significant decrease in conduction velocity compared with those in wild-type controls (Kriz et al. 2000). Further investigation revealed that NF-H knockout mice exhibited a significant decrease in outward rectification in comparison with that of wild-type control animals, indicating that NF$\mathrm{H}$ might have a specific role in modulating ion-channel function in large myelinated axons (Kriz et al. 2000). Specifically deleting NF-L or NF-M, and thus lowering NF numbers by $50 \%-90 \%$ (Elder et al. 1998a; Jacomy et al. 1999), severely inhibits axonal radial growth (Zhu et al. 1997; Jacomy et al. 1999). In contrast, NF-H deletion has little (Elder et al. 1998b) or no effect on radial growth (Rao et al. 1998; Zhu et al. 1998); however, eliminating the tail domains of both NF-H and NF-M markedly inhibits axonal caliber expansion and reduces interfilament distances (nearest-neighbor distances) (Garcia et al. 2003) by reducing the numbers of long cross-bridges between filaments (Rao et al. 2002b; Garcia et al. 2003; Rao et al. 2003).

\subsection{Novel Roles for the Individual Subunits of NFs in Synapses}

Synapses have long been considered to be degradative sites for NFs reaching terminals by axonal transport (Roots 1983). When NF proteins have been detected in synaptic fractions and bound to synaptic proteins in vitro, they have usually been considered to be axonal NF contaminants (Matus et al. 1980; Ehlers et al. 1998; Kim et al. 2002). Using multiple independent approaches, however, Yuan and col- leagues recently provided definitive evidence both for the presence of NF proteins in synapses and for a role for these proteins in synaptic function (Yuan et al. 2015c). NF assemblies isolated from synapses are distinctive. Compared with those present in axons, synaptic NF assemblies have high proportions of $\alpha$-internexin, and NF-M is present in a low state of phosphorylation. Moreover, when NF-M is deleted from mice, phosphorylation of NF-H and the proportion of NF-H relative to NF-L increase significantly in the synaptic pool compared with the total NF pool. This unique population of synaptic NF proteins is more abundant in the postsynaptic area compared with those in the presynaptic region and preterminal dendrite. The observation of 10-nm filaments in some synapses and the decoration of these filaments by immunogold antibodies against different NF proteins indicate that at least some synaptic NF subunits exist in polymerized form (Fig. 6).

Yuan and colleagues also showed that deletion of NF-M in mice, but not deletion of any other NF subunits, amplifies dopamine-D1-receptor-mediated motor responses to cocaine while redistributing postsynaptic D1-receptors from endosomes to the plasma membrane. In addition, NF-M colocalizes with D1 receptor in synaptic boutons and synaptosomal fractions, and coimmunoprecipitation of NF-M and endosomal markers also pulls down D1R, further indicating an in vivo interaction between NF-M and D1R-containing endosomal fractions. These findings are consistent with a model (Fig. 7) in which NF-M, within a synaptic cytoskeletal structure, anchors D1-receptor-containing endosomes within synapses, thereby establishing a reservoir of receptors available for rapid recycling to the synaptic plasma membrane following dopamine agonist stimulation. Without NF-M, recycling back to the surface is accentuated, favoring hypersensitivity to D1-receptor agonists. The D1 receptor has been shown to interact with the carboxy-terminal tail of NF-M (Kim et al. 2002), and it will be important for future studies to address the role of phosphorylation of this domain in regulating D1-receptor binding.

The complex heteropolymeric structure and dynamically changing phosphate topography of NF proteins has suggested that all NF proteins might serve additional biological roles beyond static structural support of the axon caliber. In fact, eliminating all NF proteins from the CNS profoundly disrupts synaptic plasticity and social memory without altering the structural integrity of synapses. Supporting this view, our further observations also indicate depressed induction of hippocampal long-term potentiation (LTP) is also NF subunit selective: Maintenance of LTP is deficient in NF-H-null mice, whereas basal neurotransmission and induction of LTP are normal in NF-M-null mice. Moreover, NF-L selectively influences dendritic spine 

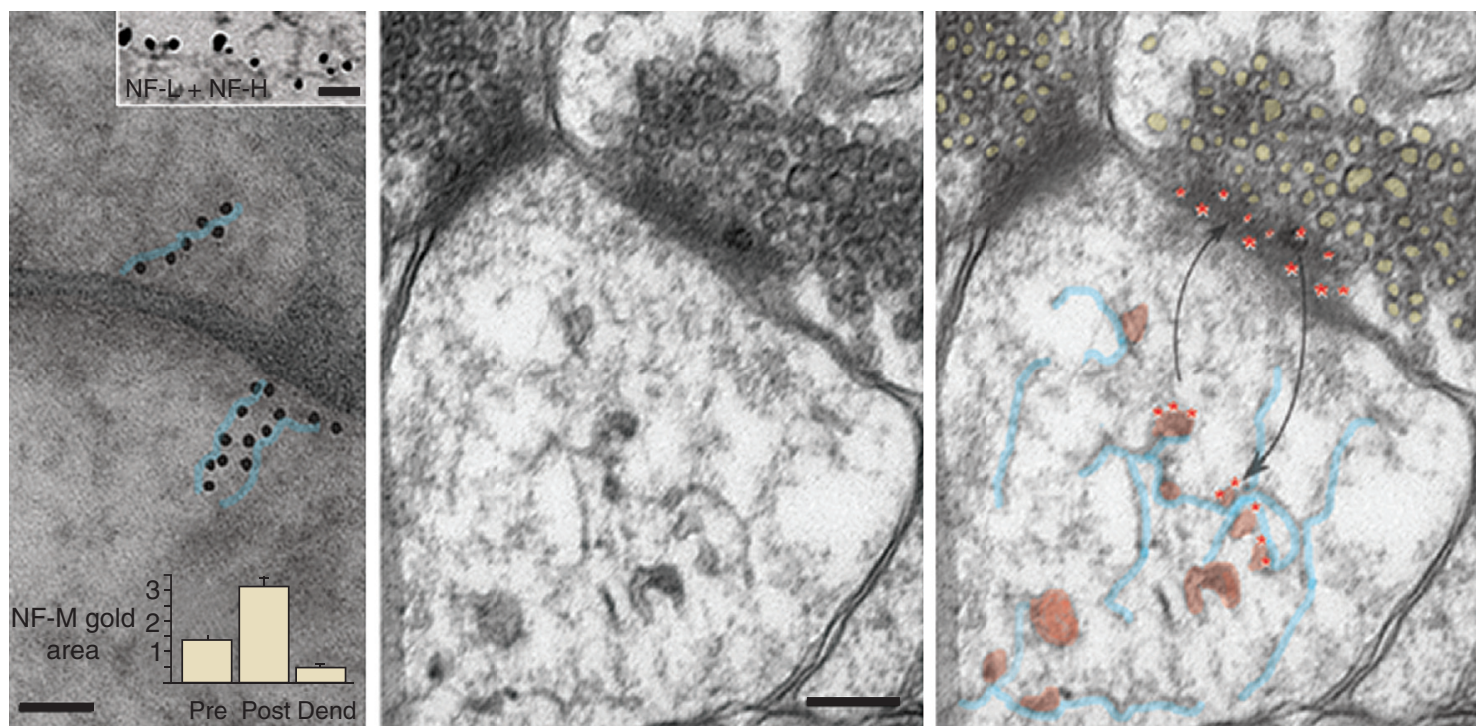

Figure 6. Functional neurofilament (NF) subunit assemblies in synapses. (Left) Immunogold-labeled antibodies against the neurofilament middle (NF-M) subunit decorating synaptic structures in a linear pattern (immunogold particles outlined in blue), suggesting the presence of short NFs and protofilament/protofibril or unit length filament assemblies. Scale bar, $60 \mathrm{~nm}$. In the upper inset, a filament within a postsynaptic bouton is decorated by immunogold antibodies to both neurofilament light (NF-L; large gold dots) and neurofilament heavy (NF-H; small gold dots). Scale bar, $50 \mathrm{~nm}$. Morphometric analysis indicates a higher density of immunogold labeling in postsynaptic boutons than in preterminal dendrites or presynaptic terminals (graph inset). (Middle) Ultrastructural image of a human synapse depicting membranous vesicles, many of which appear to be associated with a loose network of short 10-nm filaments in the postsynaptic region. Scale bar, $100 \mathrm{~nm}$. (Right) Evidence supports a biological mechanism whereby D1 dopamine receptors internalized on endosomes from the postsynaptic surface (red asterisks) dock on synaptic NF subunit assemblies (outlined in blue), where they are readily available to recycle on endosomes to the surface in response to ligand stimulation. The cartoon overlay of the EM image is the hypothetical depiction of this process. (Adapted, with permission from Macmillan Publishers Ltd., from Yuan et al. 2015b.)
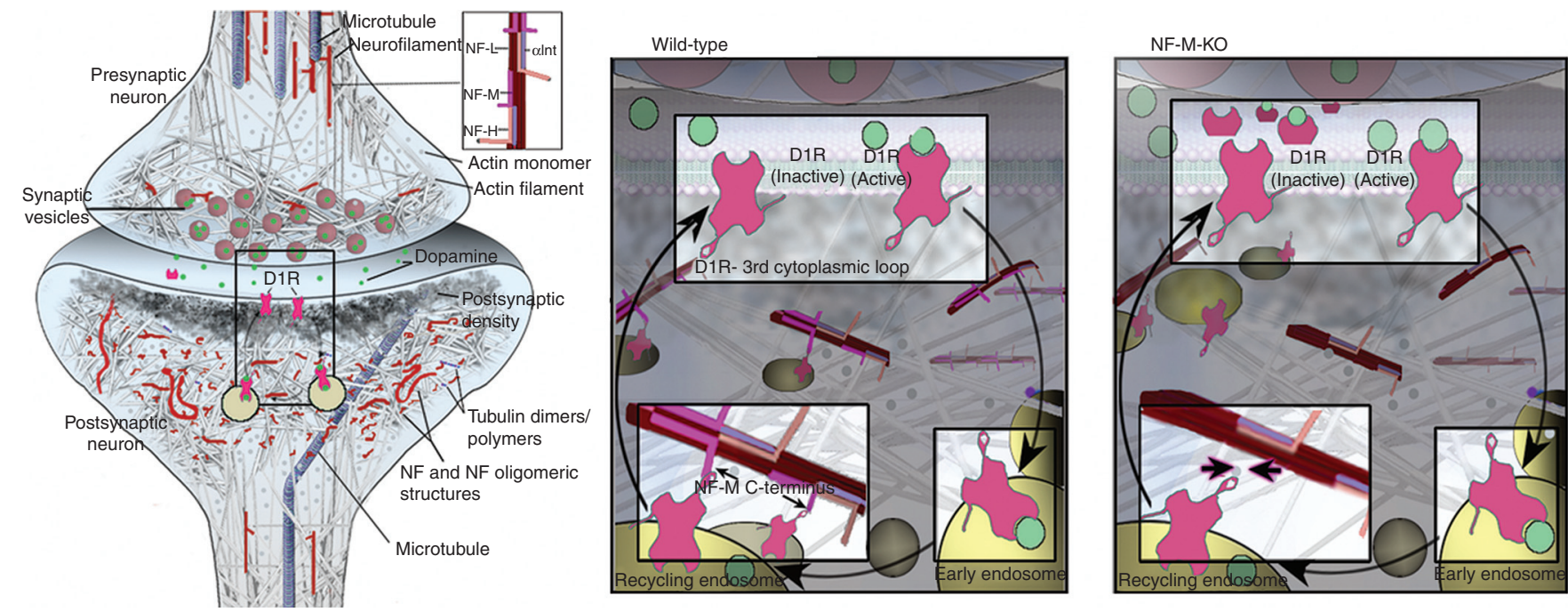

Figure 7. Model of D1-receptor (D1R)-containing endosomes anchored on Neurofilament middle (NF-M)-containing cytoskeletal assemblies. Based on collective findings on NF scaffolding functions and our D1R data on NFsubunit-null mice, we propose a model by which NF-M acts in synaptic terminals to anchor D1R-containing endosomes formed after agonist-induced internalization of membrane D1R. Retention of D1R in a readily available internal pool within the synapse would favor desensitization to D1R stimulation: In the absence of NF-M, the greater recycling back to the plasma membrane surface would favor hypersensitivity to D1R agonists, as observed in our in vivo studies. NF-L, neurofilament light; NF-H, neurofilament heavy; C-terminal, carboxyl terminal. (Adapted, with permission from Macmillan Publishers Ltd., from Yuan et al. 2015c.) 
A. Yuan et al.

and glutamate receptor function because NF-L-null mice show not only abnormalities of these membranous protrusions but also dysfunction of hippocampus-dependent spatial memory, $\mathrm{N}$-methyl-D-aspartate (NMDA) receptor protein expression, and synaptic plasticity (A Yuan, Veeranna, BS Basavarajappa, et al., unpubl.).

\section{NF SUBUNIT-INTERACTING ORGANELLES AND PROTEINS}

The NF network interacts with many proteins and organelles, including mitochondria, actin, tubulin, brain spectrin, kinases, phosphatases, molecular motors, receptors, proteases, and other degradative systems (Shaw et al. 2004; Song et al. 2012; Yuan et al. 2012a). MT organization in axons is strongly influenced by NFs. A negative regulatory influence of NFs on MT polymerization in axons was first suggested by the increased formation of MTs, despite normal tubulin levels, when axonal NF content was markedly reduced (Eyer and Peterson 1994; Fressinaud and Eyer 2014). An extensive analysis of all NF protein sequences subsequently revealed MT binding sites in the head domain of all NF subunit proteins, which inhibit MT polymerization (Bocquet et al. 2009). Moreover, peptide sequences of NF-L proteins containing these tubulin-binding sites selectively inhibit MT polymerization, cell proliferation, and tumor growth in rats (Berges et al. 2012). In addition, other manipulations that lead to depletion of axonal NFs, such as NF-L gene deletion, also increase MT number and tubulin levels (Zhu et al. 1997). Loss of NF-H and NF-M tails, or both NF-(H/M) tails, leads to an increase in total tubulin levels, as well as MT numbers in the axons (Rao et al. 1998; Zhu et al. 1998; Rao et al. 2003, 2012), suggesting the possibility of additional tubulin binding sites on NF-H/M tail domains that modulate MT dynamics in axons, as previously proposed (Hisanaga and Hirokawa 1990; Miyasaka et al. 1993). These results collectively suggest that dynamic interactions between NFs and MTs regulate the balance of these two fibrous elements so that both structural and transport functions of the axon are properly supported.

Apart from being structural elements in axons, NFs form cellular scaffolds for docking and organization of synaptic vesicles, endosomes, and the endoplasmic reticulum (ER) (Rao et al. 2002a; Balastik et al. 2008; Kim et al. 2011; Rao et al. 2011). Myosin Va in neurons binds to NF-L, and this interaction is essential for the normal distribution of ER and other organelles in the axon. Myosin V is also involved in recycling of endosomes at the synapse (Kim et al. 2002; Wang et al. 2008). It has been proposed that NFs act as "tracks" for the positioning of endosomes, lysosomes, ER, and other vesicles (Rao et al. 2011). NF-L also binds mitochondria and might regulate their dynamics. For example, mutations of NF-L causing the peripheral neuropathy Charcot-Marie-Tooth disease retard movement of mitochondria in neurons (Gentil et al. 2012). Phosphorylated NFs bind to mitochondria that have high membrane potential, suggesting another possible mechanism by which $\mathrm{NF}$-mitochondria interactions could be regulated (Wagner et al. 2003). Finally, peripherin, $\alpha$-internexin, and vimentin bind to adaptor protein-3, which might modulate positioning, content, and distribution of a set of late-endosome and lysosomal membrane proteins (Styers et al. 2004).

\section{NF PROTEINS IN DISEASE STATES}

\subsection{Primary NF Disorders}

NF defects cause multiple familial neurodegenerative disorders and might be risk factors in other diseases. In disorders involving NF gene mutations, NF aggregation and transport failure leading to further NF accumulations are often the most prominent pathological manifestations of the disease and are frequently considered primary pathogenic factors leading to general axonal dysfunction and degeneration. In these disorders, the close link between defective subunit assembly and perikaryal aggregation of all subunits underscores other evidence that assembly competence is crucial for axonal transport of NF subunits. When this balance is altered by overexpressing one subunit in genetic mouse models or by other experimental manipulations (Gibb et al. 1998), the outcome is commonly NF protein aggregation in the cell body and/or proximal axon and degeneration that particularly affects long axons. Thus, motor neuron disease with these pathological characteristics develops in mice overexpressing mouse NF-L (Xu et al. 1993), mouse peripherin (Beaulieu et al. 1999), human NF-H (Cote et al. 1993), or human NFM (Fig. 8) (Gama Sosa et al. 2003), or expressing mutant mouse NF-L (Lee et al. 1994). It has also been shown that the organization of the NF network can be altered by raising the concentration of NF-H microinjected into a single cultured dorsal root ganglion neuron. This is followed by fragmentation of the Golgi complex, accumulation of mitochondria within the proximal regions of neurites, peripheralization of the nucleus, significant decrease in neurite caliber, and later appearance of abnormally phosphorylated neurofilament heavy chain ( $\mathrm{pNF}-$ H) (Straube-West et al. 1996).

More than 14 NF-L gene mutations are known to cause type $2 \mathrm{E}$ and $1 \mathrm{~F}$ forms of Charcot-Marie-Tooth disease (CMT2E/CMT1F) (Fig. 9), the most common inherited peripheral nerve disorder (Mersiyanova et al. 2000; De Jonghe et al. 2001; Georgiou et al. 2002; Yoshihara et al. 

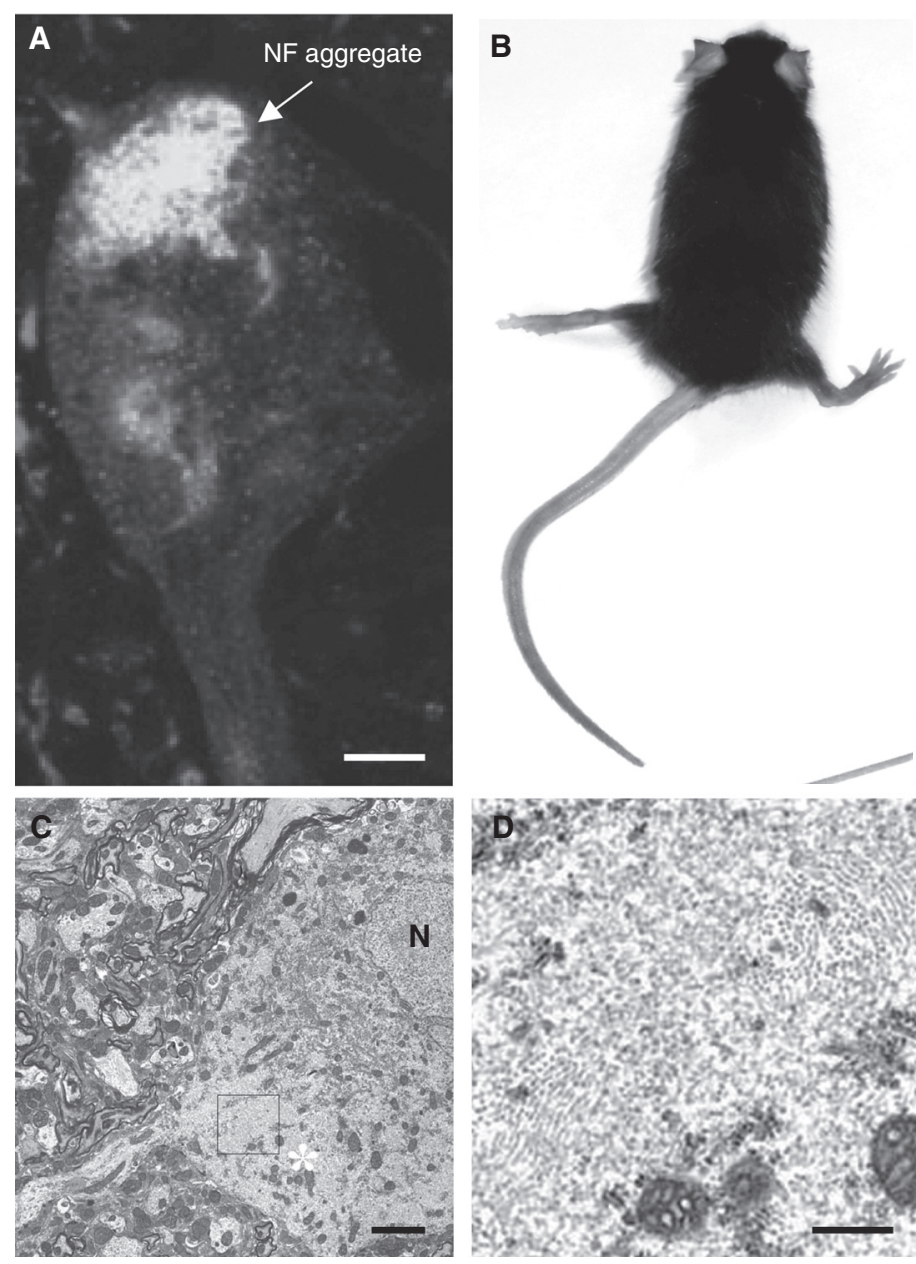

Figure 8. Abnormal neurofilament (NF) accumulation in neurological diseases. $(A)$ Inclusions containing peripherin, neurofilament light (NF-L), neurofilament middle (NF-M), and neurofilament heavy (NF-H) (identified by specific antibodies) detected in cell bodies of the remaining motor nerve cells of a patient with the D141Y mutation of peripherin. (Adapted, with permission, from Leung et al. 2004, (C) John Wiley and Sons, Inc.) (B) A 7-month-old transgenic mouse expressing human NF-M and displaying hind-limb paralysis. Note the abnormal posture and the splaying of the hind limbs owing to muscle weakness and paralysis. Overexpression of NFs leads to motor neuron dysfunction. $(C)$ Electron micrograph showing an abnormal motor neuron from the human NF-M transgenic mouse in $B$. (Adapted, with permission from Elsevier, from Gama Sosa et al. 2003.) In the cell body of the neuron, organelles are concentrated toward the nucleus $(\mathrm{N})$, and large numbers of $10-\mathrm{nm}$ filaments are present in the area marked with a white asterisk. The area outlined by the black box in $C$ is enlarged in $D$. Scale bars, $5 \mu \mathrm{m}(A, C) ; 1 \mu \mathrm{m}(D)$.
2002; Jordanova et al. 2003; Choi et al. 2004; Zuchner et al. 2004). CMT2E/1F is typically inherited in an autosomal dominant manner, although a few families with autosomal recessive CMT2E/1F (caused by homozygous nonsense mutations of the NF-L gene) have been reported (Abe et al. 2009; Yum et al. 2009). Most NF-L gene mutations are missense, whereas other mutations of NF-L delete the gene encoding NF-L. These disease-causing NF-L mutations have been shown to disrupt both the assembly and axonal transport of NF proteins (Brownlees et al. 2002; Perez-Olle et al. 2002, 2005; Sasaki et al. 2006) and induce axonopathies characterized by reduced axon calibers and impaired nerve conduction.

Genetic alterations of other NF subunits can also be associated with neurological disease. Susceptibility to amyotrophic lateral sclerosis (ALS) is increased by certain peripherin mutations (Gros-Louis et al. 2004; Leung et al. 2004; Corrado et al. 2011) and by polymorphisms of the gene encoding NF-H (Figlewicz et al. 1994; Tomkins et al. 1998; Al-Chalabi et al. 1999). Point and deletion mutations in the NF-M rod domain have been linked, respectively, to familial Parkinson's disease (Lavedan et al. 2002) and Alzheimer's disease (Fig. 9) (Wang et al. 2002). Although a mutation in the gene encoding $\alpha$-internexin has not yet been identified, the accumulation of $\alpha$-internexin is a neuropathological hallmark of NF protein aggregates in neurofilament inclusion body disease (NIBD), a form of frontotemporal dementia (Cairns et al. 2004). Transgenic mice overexpressing $\alpha$-internexin develop progressive loss of neurons, together with deficits in motor coordination (Ching et al. 1999).

Loss of NF subunit function can induce neuronal abnormalities by reducing the NF content, and thus the calibers, of large axons, leading to atrophy of these fibers and decreased conduction velocities. Spontaneous mutant Japanese quail (quv), which lack NFs as the result of a premature translation terminator in the gene encoding NF-L (Ohara et al. 1993; Toyoshima et al. 2000), develop generalized ataxia and a characteristic quivering behavior (Yamasaki et al. 1991) associated with reduced conduction velocity (Sakaguchi et al. 1993). Deletion of NF-H (Elder et al. 1998b) and NF-M (Elder et al. 1999) in mice also 
A. Yuan et al.

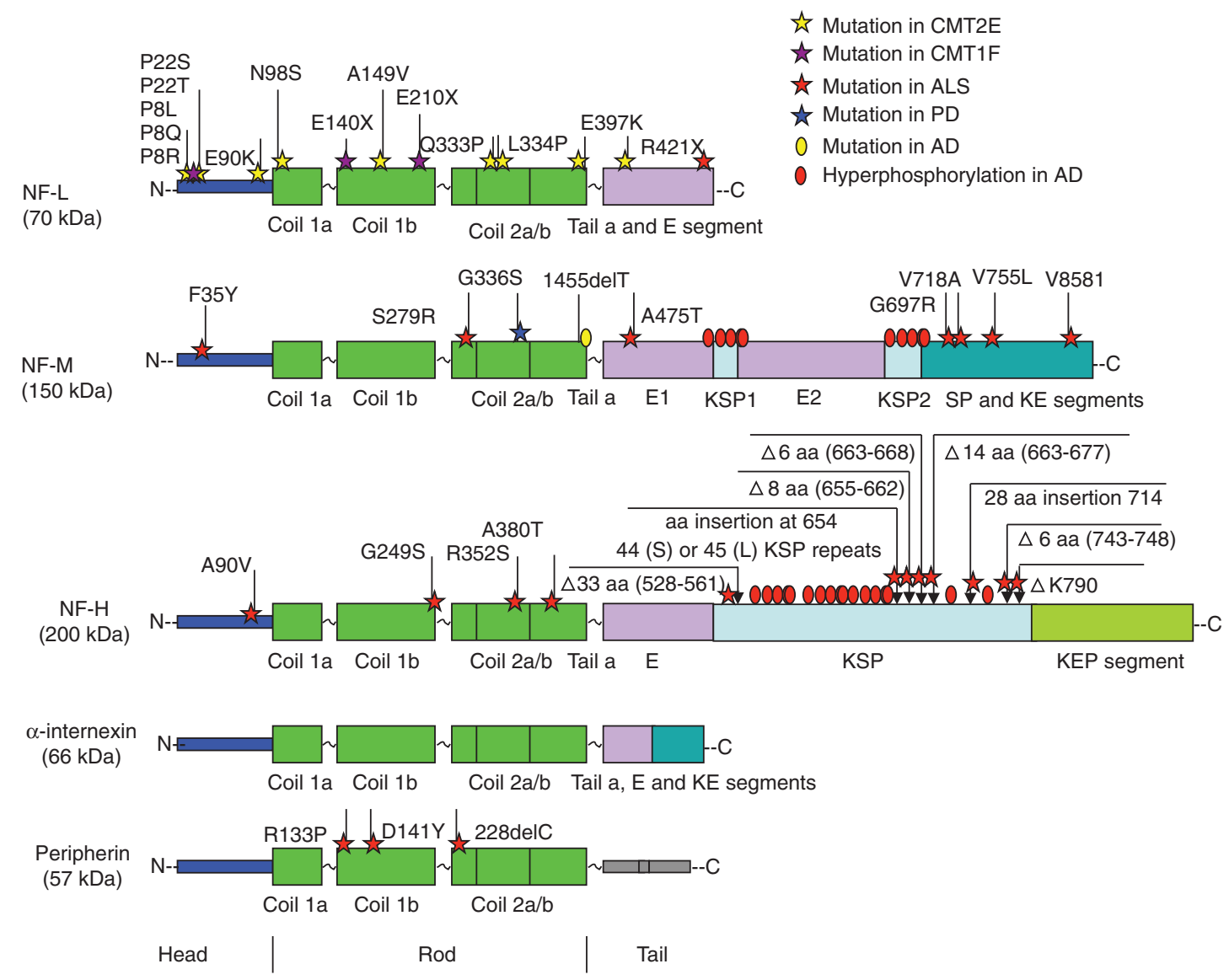

Figure 9. Neurofilament (NF) protein mutations and disease. The locations of mutations at sites on the different domains of NF subunits-neurofilament light (NF-L), neurofilament middle (NF-M), neurofilament heavy $(\mathrm{NF}-\mathrm{H})$, and peripherin - are shown in relation to their occurrence in neuropsychiatric diseases (Jordanova et al. 2003; Leung et al. 2004). No disease mutations of $\alpha$-internexin have been reported in neuropsychiatric diseases. AD, Alzheimer's disease; ALS, amyotrophic lateral sclerosis; CMT, Charcot-Marie-Tooth disease; PD, Parkinson's disease; E segment, glutamic-acid-rich segment; E1, glutamic-acid-rich segment 1; E2, glutamic-acid-rich segment 2; KE, lysine-glutamic acid; KEP, lysine-glutamic acid-proline; SP, serine-proline; KSP, lysine-serine-proline.

reduces the diameter of large-caliber axons and induces age-related atrophy of motor axons.

Exposure to a variety of chemical agents, such as $\beta, \beta^{\prime}-$ iminodipropionitrile (IDPN), aluminum, lead, acrylamide, arsenic, carbon disulfide, and 2,5-hexanedione, can chemically modify NF subunits, leading to neurodegeneration characterized by accumulation of phosphorylated NFs (Llorens 2013). IDPN induces abnormal cross-linking of hyperphosphorylated NFs, probably mediated through the NF-H subunit (Zhu et al. 1998), resulting in NF aggregation and subsequent segregation from MTs (Eyer et al. 1989).

\subsection{Secondary NF Disorders}

Mutations other than those affecting NF genes can secondarily disrupt transport of NFs specifically and lead to general transport failure. These include mutations of heat-shock 27-kDa protein 1 (HSPB1) in CMT2F (Evgrafor et al. 2004), gigaxonin in giant axonal neuropathy (Bomont et al. 2000), and superoxide dismutase superoxide dismutase 1 (SOD1) in ALS (Zhang et al. 1997). Interestingly, HSPB1 and SOD1 are both carried in slow axonal transport (Yuan 1997; Borchelt et al. 1998), in which they might play a role in NF transport and assembly (Ackerley et al. 2006) or in maintaining stability of the NF network (Menzies et al. 2002). Gigaxonin, an E3 ligase adaptor, can bind to microtubule-associated protein 1B (MAP1B) and control its degradation (Ding et al. 2002; Allen et al. 2005). Mutations of the gigaxonin gene impair NF degradation, resulting in an excess of NFs in the axons, impaired conduction of action potentials, and, eventually, degeneration of both motor and sensory neurons (Ganay et al. 2011; Mahammad et al. 2013). A deficiency of ubiquitin ligase tripartite motif containing 2 (TRIM2) (Balastik et al. 2008) or multisynthetase 
complex p43 (Zhu et al. 2009) causes NF-L accumulation and disorganization, leading to neurodegeneration. Recently, it has been reported that CMT2B disease-causing RAB7A mutant proteins show an interaction with peripherin, suggesting that abnormal NF function could be a key intermediate in the pathogenesis of this disease (Cogli et al. 2013). More recently, a heterozygous missense mutation in the gene encoding the PKA type 1- $\beta$ regulatory subunit (PRKAR1B) has been identified in a novel late-onset familial NF-related disorder presenting with dementia and/or parkinsonism, suggesting that an altered phosphorylation state of amino-terminal head and carboxy-terminal tail domains of NF subunits could be involved (Wong et al. 2014).

\section{NF PROTEINS AS POTENTIAL MARKERS OF DISEASE AND INJURY}

NF compaction, characterized by a high packing density of NFs near the site of traumatic injury to axons (Hall and Lee 1995), is believed to result from modifications of NF-M side arms that reduce the spacing between NFs (Hall and Lee 1995; Povlishock et al. 1997; Okonkwo et al. 1998). This phenomenon is thought to involve the related events of $\mathrm{Ca}^{2+}$ elevation and calpain activation (Shaw et al. 2004), as well as, possibly, other proteolytic modifications on NF$\mathrm{M}$ that expose an epitope recognized by the RMO14 antibody, a commonly used marker of traumatic nerve injury (Hollenbeck and Bray 1987; Suzuki et al. 1988; Song et al. 2012).

Because NF proteins are enriched in axons and might be released from damaged or diseased axons in significant amounts into blood and cerebrospinal fluid (CSF), their elevated levels in either CSF or serum are often used as potential biomarkers of axonal injury, axonal loss, and neuronal death, although they have not been shown to have diagnostic utility for any given disease. Soluble pNF$\mathrm{H}$ is undetectable in the sera of normal animals but is readily detectable in the sera of adult rats following various types of experimental spinal cord injury and traumatic brain injury (Shaw et al. 2005; Anderson et al. 2008). It has been suggested that pNF-H and NF-L could serve as biomarkers for monitoring axonal degeneration in ALSmodel rodents and as potential biomarkers of disease progression in ALS patients (Brettschneider et al. 2006b; Boylan et al. 2009; Gaiottino et al. 2013). The presence of NF subunits in serum is also being actively investigated as a potential prognostic indicator in multiple sclerosis (Gresle et al. 2011; Teunissen and Khalil 2012) and to assess nerve damage in patients suffering from severe burns (Gatson et al. 2015) or spinal cord injury (Kuhle et al. 2015).

NF proteins are also being used to identify ongoing axonal degeneration in dementias. Higher than normal lev- els in CSF of NF-L and NF-H have been reported in Alzheimer's disease, frontotemporal dementia, and vascular dementia (Sjogren et al. 2001; Brettschneider et al. 2006a; Petzold et al. 2007; Pijnenburg et al. 2007; Bjerke et al. 2011) and correlate with disease severity in a recent study of frontotemporal dementia (Scherling et al. 2014). A more recent study has suggested that the CSF NF-L concentration is increased by the early clinical stage of Alzheimer's disease and is associated with cognitive deterioration and structural changes over time (Zetterberg et al. 2016). Levels of CSF NF-H and NF-L might also have value in discriminating atypical parkinsonian syndromes from Parkinson's disease.

\section{NF BIOLOGY - THE NEXT DECADE}

Although much has been learned about the biology of NFs, fundamental questions remain unanswered, especially regarding the possible functions of NFs beyond the structural support role shared with other classes of IFs. Although neurons have unique structural needs because of their asymmetric geometries, it is not clearly evident from comparisons with other cells why these known structural needs necessarily require the complexity of subunit composition and regulation by phosphorylation that characterizes NFs. In the future, it is likely that insights into this question will emerge by a closer examination of interactions of the individual NF subunits, either within filaments or as oligomeric assemblies, with other proteins and organelles. There is a strong need to understand the significance of the interactions between specific NF subunits and neurotransmitter receptors in vivo. How broad is the synaptic role of NF subunits, and what are the implications of these roles for psychiatric disease, not just neurological disorders? What do the changes in NF structure and phosphorylation linked to NIBD, Parkinson's disease, and addictive states tell us about the neural mechanisms underlying these disorders? Even in the neurodegenerative diseases caused by NF mutation, is neuronal function disrupted by one common mechanism or multiple mechanisms, and do these involve a loss of function or gain of toxic function of NF proteins?

As these aspects of NF function are being explored, answers to additional questions about the fundamental biology of NF will also need to be pursued. Much additional insight is needed about NF protein turnover and how it is regulated. For example, are there functional roles for the abundant NF subunit fragments that are generated by proteolysis? How variable are the assembly forms of NF subunits and what is the functional significance of the variation in subunit composition of NFs seen in different neurons? Which molecular motors interact with which NF proteins to mediate slow NF transport and what are the signals to NFs to trigger their incorporation into the axonal 
cytoskeleton? Forthcoming answers to these and other questions are likely to alter any preconception that we are presently close to fully understanding the scope of NF roles in neurons. These future insights should reward us with a better understanding of neural function and exciting new ideas on how to translate this information into disease therapies.

\section{ACKNOWLEDGMENTS}

We thank Nicole Gogel for manuscript preparation. This work was supported by Grant 5R01AG005604 from the National Institutes on Aging.

\section{REFERENCES}

* Reference is also in this subject collection.

Abe A, Numakura C, Saito K, Koide H, Oka N, Honma A, Kishikawa Y, Hayasaka K. 2009. Neurofilament light chain polypeptide gene mutations in Charcot-Marie-Tooth disease: Nonsense mutation probably causes a recessive phenotype. J Hum Genet 54: 94-97.

Ackerley S, Thornhill P, Grierson AJ, Brownlees J, Anderton BH, Leigh PN, Shaw CE, Miller CC. 2003. Neurofilament heavy chain side arm phosphorylation regulates axonal transport of neurofilaments. J Cell Biol 161: 489-495.

Ackerley S, James PA, Kalli A, French S, Davies KE, Talbot K. 2006. A mutation in the small heat-shock protein HSPB1 leading to distal hereditary motor neuronopathy disrupts neurofilament assembly and the axonal transport of specific cellular cargoes. Human Mol Genet 15: $347-354$.

Alami NH, Jung P, Brown A. 2009. Myosin Va increases the efficiency of neurofilament transport by decreasing the duration of long-term pauses. J Neurosci 29: 6625-6634.

Al-Chalabi A, Andersen PM, Nilsson P, Chioza B, Andersson JL, Russ C, Shaw CE, Powell JF, Leigh PN. 1999. Deletions of the heavy neurofilament subunit tail in amyotrophic lateral sclerosis. Hum Mol Genet 8: $157-164$.

Aletta JM, Angeletti R, Liem RK, Purcell C, Shelanski ML, Greene LA. 1988. Relationship between the nerve growth factor-regulated clone 73 gene product and the 58-kilodalton neuronal intermediate filament protein (peripherin). J Neurochem 51: 1317-1320.

Aletta JM, Shelanski ML, Greene LA. 1989. Phosphorylation of the peripherin $58-\mathrm{kDa}$ neuronal intermediate filament protein. Regulation by nerve growth factor and other agents. J Biol Chem 264: 4619-4627.

Allen E, Ding J, Wang W, Pramanik S, Chou J, Yau V, Yang Y. 2005. Gigaxonin-controlled degradation of MAP1B light chain is critical to neuronal survival. Nature 438: 224-228.

Anderson KJ, Scheff SW, Miller KM, Roberts KN, Gilmer LK, Yang C, Shaw G. 2008. The phosphorylated axonal form of the neurofilament subunit NF-H (pNF-H) as a blood biomarker of traumatic brain injury. J Neurotrauma 25: 1079-1085.

Angelastro JM, Ho CL, Frappier T, Liem RK, Greene LA. 1998. Peripherin is tyrosine-phosphorylated at its carboxyl-terminal tyrosine. J Neurochem 70: 540-549.

Angelides KJ, Smith KE, Takeda M. 1989. Assembly and exchange of intermediate filament proteins of neurons: Neurofilaments are dynamic structures. J Cell Biol 108: 1495-1506.

Baas PW, Brown A. 1997. Slow axonal transport: The polymer transport model. Trends Cell Biol 7: 380-384.

Balastik M, Ferraguti F, Pires-da Silva A, Lee TH, Alvarez-Bolado G, Lu KP, Gruss P. 2008. Deficiency in ubiquitin ligase TRIM2 causes accu- mulation of neurofilament light chain and neurodegeneration. Proc Natl Acad Sci 105: 12016-12021.

Barry DM, Carpenter C, Yager C, Golik B, Barry KJ, Shen H, Mikse O, Eggert LS, Schulz DJ, Garcia ML. 2010. Variation of the neurofilament medium KSP repeat sub-domain across mammalian species: Implications for altering axonal structure. J Exp Biol 213: 128-136.

Beaulieu JM, Nguyen MD, Julien JP. 1999. Late onset of motor neurons in mice overexpressing wild-type peripherin. J Cell Biol 147: 531-544.

Berges R, Balzeau J, Peterson AC, Eyer J. 2012. A tubulin binding peptide targets glioma cells disrupting their microtubules, blocking migration, and inducing apoptosis. Mol Ther 20: 1367-1377.

Bjerke M, Zetterberg H, Edman A, Blennow K, Wallin A, Andreasson U. 2011. Cerebrospinal fluid matrix metalloproteinases and tissue inhibitor of metalloproteinases in combination with subcortical and cortical biomarkers in vascular dementia and Alzheimer's disease. J Alzheimer's Dis 27: 665-676.

Bocquet A, Berges R, Frank R, Robert P, Peterson AC, Eyer J. 2009. Neurofilaments bind tubulin and modulate its polymerization. J Neurosci 29: 11043-11054.

Bomont P, Cavalier L, Blondeau F, Ben Hamida C, Belal S, Tazir M, Demir E, Topaloglu H, Korinthenberg R, Tuysuz B, et al. 2000. The gene encoding gigaxonin, a new member of the cytoskeletal BTB/kelch repeat family, is mutated in giant axonal neuropathy. Nat Genet 26: $370-374$.

Borchelt DR, Wong PC, Becher MW, Pardo CA, Lee MK, Xu ZS, Thinakaran G, Jenkins NA, Copeland NG, Sisodia SS, et al. 1998. Axonal transport of mutant superoxide dismutase 1 and focal axonal abnormalities in the proximal axons of transgenic mice. Neurobiol Dis 5: $27-35$.

Boylan K, Yang C, Crook J, Overstreet K, Heckman M, Wang Y, Borchelt D, Shaw G. 2009. Immunoreactivity of the phosphorylated axonal neurofilament $\mathrm{H}$ subunit ( $\mathrm{pNF}-\mathrm{H}$ ) in blood of ALS model rodents and ALS patients: Evaluation of blood pNF-H as a potential ALS biomarker. J Neurochem 111: 1182-1191.

Brettschneider J, Petzold A, Schottle D, Claus A, Riepe M, Tumani H. 2006a. The neurofilament heavy chain (NfH) in the cerebrospinal fluid diagnosis of Alzheimer's disease. Dement Geriatr Cogn Disord 21: 291-295.

Brettschneider J, Petzold A, Sussmuth SD, Ludolph AC, Tumani H. 2006b. Axonal damage markers in cerebrospinal fluid are increased in ALS. Neurology 66: 852-856.

Brown A. 2000. Slow axonal transport: Stop and go traffic in the axon. Nat Rev Mol Cell Biol 1: 153-156.

Brown ME, Bridgman PC. 2004. Myosin function in nervous and sensory systems. J Neurobiol 58: 118-130.

Brownlees J, Ackerley S, Grierson AJ, Jacobsen NJ, Shea K, Anderton BH, Leigh PN, Shaw CE, Miller CC. 2002. Charcot-Marie-Tooth disease neurofilament mutations disrupt neurofilament assembly and axonal transport. Hum Mol Genet 11: 2837-2844.

Burton PR, Wentz MA. 1992. Neurofilaments are prominent in bullfrog olfactory axons but are rarely seen in those of the tiger salamander, Ambystoma tigrinum. J Comp Neurol 317: 396-406.

Cairns NJ, Zhukareva V, Uryu K, Zhang B, Bigio E, Mackenzie IR, Gearing M, Duyckaerts C, Yokoo H, Nakazato Y, et al. 2004. $\alpha$-internexin is present in the pathological inclusions of neuronal intermediate filament inclusion disease. Am J Pathol 164: 2153-2161.

Carden MJ, Trojanowski JQ, Schlaepfer WW, Lee VM. 1987. Two-stage expression of neurofilament polypeptides during rat neurogenesis with early establishment of adult phosphorylation patterns. J Neurosci 7: 3489-3504.

Carpenter DA, Ip W. 1996. Neurofilament triplet protein interactions: Evidence for the preferred formation of NF-L-containing dimers and a putative function for the end domains. J Cell Sci 109: 2493-2498.

Chen J, Nakata T, Zhang Z, Hirokawa N. 2000. The C-terminal tail domain of neurofilament protein-H (NF-H) forms the crossbridges and regulates neurofilament bundle formation. J Cell Sci 113: 38613869. 
Ching GY, Chien CL, Flores R, Liem RK. 1999. Overexpression of $\alpha-$ internexin causes abnormal neurofilamentous accumulations and motor coordination deficits in transgenic mice. J Neurosci 19: 29742986.

Choi BO, Lee MS, Shin SH, Hwang JH, Choi KG, Kim WK, Sunwoo IN, Kim NK, Chung KW. 2004. Mutational analysis of PMP22, MPZ, GJB1, EGR2 and NEFL in Korean Charcot-Marie-Tooth neuropathy patients. Hum Mutat 24: 185-186.

Cogli L, Progida C, Thomas CL, Spencer-Dene B, Donno C, Schiavo G, Bucci C. 2013. Charcot-Marie-Tooth type 2B disease-causing RAB7A mutant proteins show altered interaction with the neuronal intermediate filament peripherin. Acta Neuropathol 125: 257-272.

Collard JF, Cote F, Julien JP. 1995. Defective axonal transport in a transgenic mouse model of amyotrophic lateral sclerosis. Nature 375: 6164.

Corrado L, Carlomagno Y, Falasco L, Mellone S, Godi M, Cova E, Cereda C, Testa L, Mazzini L, D’Alfonso S. 2011. A novel peripherin gene (PRPH) mutation identified in one sporadic amyotrophic lateral sclerosis patient. Neurobiol Aging 32: 552 e551-e556.

Cote F, Collard JF, Julien JP. 1993. Progressive neuronopathy in transgenic mice expressing the human neurofilament heavy gene: A mouse model of amyotrophic lateral sclerosis. Cell 73: 35-46.

Dahlstrand J, Zimmerman LB, McKay RD, Lendahl U. 1992. Characterization of the human nestin gene reveals a close evolutionary relationship to neurofilaments. J Cell Sci 103: 589-597.

De Jonghe P, Mersivanova I, Nelis E, Del Favero J, Martin JJ, Van Broeckhoven C, Evgrafov O, Timmerman V. 2001. Further evidence that neurofilament light chain gene mutations can cause Charcot-Marie-Tooth disease type 2E. Ann Neurol 49: 245-249.

de Waegh SM, Lee VM, Brady ST. 1992. Local modulation of neurofilament phosphorylation, axonal caliber, and slow axonal transport by myelinating Schwann cells. Cell 68: 451-463.

Ding J, Liu JJ, Kowal AS, Nardine T, Bhattacharya P, Lee A, Yang Y. 2002. Microtubule-associated protein 1B: A neuronal binding partner for gigaxonin. J Cell Biol 158: 427-433.

Ehlers MD, Fung ET, O’Brien RJ, Huganir RL. 1998. Splice variant-specific interaction of the NMDA receptor subunit NR1 with neuronal intermediate filaments. J Neurosci 18: 720-730.

Elder GA, Friedrich VL Jr, Bosco P, Kang C, Gourov A, Tu PH, Lee VM, Lazzarini RA. 1998a. Absence of the mid-sized neurofilament subunit decreases axonal calibers, levels of light neurofilament (NF-L), and neurofilament content. J Cell Biol 141: 727-739.

Elder GA, Friedrich VL Jr, Kang C, Bosco P, Gourov A, Tu PH, Zhang B, Lee VM, Lazzarini RA. 1998b. Requirement of heavy neurofilament subunit in the development of axons with large calibers. J Cell Biol 143: 195-205.

Elder GA, Friedrich VL Jr, Margita A, Lazzarini RA. 1999. Age-related atrophy of motor axons in mice deficient in the mid-sized neurofilament subunit. J Cell Biol 146: 181-192.

Elluru RG, Bloom GS, Brady ST. 1995. Fast axonal transport of kinesin in the rat visual system: Functionality of kinesin heavy chain isoforms. Mol Biol Cell 6: 21-40.

Evgrafov OV, Mersiyanova I, Irobi J, Van Den Bosch L, Dierick I, Leung CL, Schagina O, Verpoorten N, Van Impe K, Fedotov V, et al. 2004. Mutant small heat-shock protein 27 causes axonal Charcot-MarieTooth disease and distal hereditary motor neuropathy. Nat Genet 36: 602-606.

Eyer J, Peterson A. 1994. Neurofilament-deficient axons and perikaryal aggregates in viable transgenic mice expressing a neurofilament- $\beta$ galactosidase fusion protein. Neuron 12: 389-405.

Eyer J, McLean WG, Leterrier JF. 1989. Effect of a single dose of $\beta, \beta^{\prime}-$ iminodipropionitrile in vivo on the properties of neurofilaments in vitro: Comparison with the effect of iminodipropionitrile added directly to neurofilaments in vitro. J Neurochem 52: 1759-1765.

Faussone-Pellegrini MS, Matini P, DeFelici M. 1999. The cytoskeleton of the myenteric neurons during murine embryonic life. Anat Embryol 199: $459-469$.
Figlewicz DA, Krizus A, Martinoli MG, Meininger V, Dib M, Rouleau GA, Julien JP. 1994. Variants of the heavy neurofilament subunit are associated with the development of amyotrophic lateral sclerosis. Hum Mol Genet 3: 1757-1761.

Francis F, Roy S, Brady ST, Black MM. 2005. Transport of neurofilaments in growing axons requires microtubules but not actin filaments. $J$ Neurosci Res 79: 442-450.

Franke WW. 1987. Nuclear lamins and cytoplasmic intermediate filament proteins: A growing multigene family. Cell 48: 3-4.

Frappier T, Regnouf F, Pradel LA. 1987. Binding of brain spectrin to the 70-kDa neurofilament subunit protein. Eur J Biochem 169: 651-657.

Frappier T, Stetzkowski-Marden F, Pradel LA. 1991. Interaction domains of neurofilament light chain and brain spectrin. Biochem J 275: 521527.

Frappier T, Derancourt J, Pradel LA. 1992. Actin and neurofilament binding domain of brain spectrin $\beta$ subunit. Eur J Biochem 205: $85-91$.

Fressinaud C, Eyer J. 2014. Neurofilament-tubulin binding site peptide NFL-TBS.40-63 increases the differentiation of oligodendrocytes in vitro and partially prevents them from lysophosphatidyl choline toxiciy. J Neurosci Res 92: 243-253.

Friede RL, Samorajski T. 1970. Axon caliber related to neurofilaments and microtubules in sciatic nerve fibers of rats and mice. Anat Rec 167: $379-387$.

Fuchs E, Weber K. 1994. Intermediate filaments: Structure, dynamics, function, and disease. Annu Rev Biochem 63: 345-382.

Gaiottino J, Norgren N, Dobson R, Topping J, Nissim A, Malaspina A, Bestwick JP, Monsch AU, Regeniter A, Lindberg RL, et al. 2013. Increased neurofilament light chain blood levels in neurodegenerative neurological diseases. PloS ONE 8: e75091.

Gama Sosa MA, Friedrich VL Jr, DeGasperi R, Kelley K, Wen PH, Senturk E, Lazzarini RA, Elder GA. 2003. Human midsized neurofilament subunit induces motor neuron disease in transgenic mice. Exp Neurol 184: $408-419$.

Ganay T, Boizot A, Burrer R, Chauvin JP, Bomont P. 2011. Sensory-motor deficits and neurofilament disorganization in gigaxonin-null mice. Mol Neurodegener 6: 25.

Garcia ML, Lobsiger CS, Shah SB, Deerinck TJ, Crum J, Young D, Ward CM, Crawford TO, Gotow T, Uchiyama Y, et al. 2003. NF-M is an essential target for the myelin-directed 'outside-in' signaling cascade that mediates radial axonal growth. J Cell Biol 163: 1011-1020.

Gatson JW, Liu MM, Rivera-Chavez FA, Minei JP, Wolf SE. 2015. Serum levels of neurofilament- $\mathrm{H}$ are elevated in patients suffering from severe burns. J Burn Care Res 36: 545-550.

Geisler N, Kaufmann E, Fischer S, Plessmann U, Weber K. 1983. Neurofilament architecture combines structural principles of intermediate filaments with carboxy-terminal extensions increasing in size between triplet proteins. EMBO J 2: 1295-1302.

Gentil BJ, Minotti S, Beange M, Baloh RH, Julien JP, Durham HD. 2012. Normal role of the low-molecular-weight neurofilament protein in mitochondrial dynamics and disruption in Charcot-Marie-Tooth disease. FASEB J 26: 1194-1203.

Georgiou DM, Zidar J, Korosec M, Middleton LT, Kyriakides T, Christodoulou K. 2002. A novel NF-L mutation Pro22Ser is associated with CMT2 in a large Slovenian family. Neurogenetics 4: 93-96.

Giasson BI, Mushynski WE. 1997a. Developmentally regulated stabilization of neuronal intermediate filaments in rat cerebral cortex. Neurosci Lett 229: $77-80$.

Giasson BI, Mushynski WE. 1997b. Study of proline-directed protein kinases involved in phosphorylation of the heavy neurofilament subunit. J Neurosci 17: 9466-9472.

Giasson BI, Mushynski WE. 1998. Intermediate filament disassembly in cultured dorsal root ganglion neurons is associated with amino-terminal head domain phosphorylation of specific subunits. J Neurochem 70: $1869-1875$.

Giasson BI, Cromlish JA, Athlan ES, Mushynski WE. 1996. Activation of cyclic AMP-dependent protein kinase in okadaic acid-treated neu- 
rons potentiates neurofilament fragmentation and stimulates phosphorylation of Ser2 in the low-molecular-mass neurofilament subunit. J Neurochem 66: 1207-1213.

Gibb BJ, Brion JP, Brownlees J, Anderton BH, Miller CC. 1998. Neuropathological abnormalities in transgenic mice harbouring a phosphorylation mutant neurofilament transgene. J Neurochem 70: 492500 .

Goldman RD, Grin B, Mendez MG, Kuczmarski ER. 2008. Intermediate filaments: Versatile building blocks of cell structure. Curr Opin Cell Biol 20: 28-34.

Gonda Y, Nishizawa K, Ando S, Kitamura S, Minoura Y, Nishi Y, Inagaki M. 1990. Involvement of protein kinase $C$ in the regulation of assembly-disassembly of neurofilaments in vitro. Biochem Biophys Res Commun 167: 1316-1325.

Grant P, Pant HC. 2000. Neurofilament protein synthesis and phosphorylation. J Neurocytol 29: 843-872.

Gresle MM, Butzkueven H, Shaw G. 2011. Neurofilament proteins as body fluid biomarkers of neurodegeneration in multiple sclerosis. Mult Scler Int 2011: 315406.

Gros-Louis F, Lariviere R, Gowing G, Laurent S, Camu W, Bouchard JP, Meininger V, Rouleau GA, Julien JP. 2004. A frameshift deletion in peripherin gene associated with amyotrophic lateral sclerosis. J Biol Chem 279: 45951-45956.

Guerette D, Khan PA, Savard PE, Vincent M. 2007. Molecular evolution of type VI intermediate filament proteins. BMC Evolutionary Biol 7: 164.

Guru SC, Shetty KT, Shankar SK. 1991. Effect of chronic ethanol ingestion on phosphate content of neurofilament proteins and neurofilament associated protein phosphatase in rat spinal cord. Neurochem Res 16: $1193-1197$.

Hall GF, Kosik KS. 1993. Axotomy-induced neurofilament phosphorylation is inhibited in situ by microinjection of PKA and PKC inhibitors into identified lamprey neurons. Neuron 10: 613-625.

Hall GF, Lee VM. 1995. Neurofilament sidearm proteolysis is a prominent early effect of axotomy in lamprey giant central neurons. J Comp Neurol 353: 38-49.

Hall GF, Chu B, Lee S, Liu Y, Yao J. 2000. The single neurofilament subunit of the lamprey forms filaments and regulates axonal caliber and neuronal size in vivo. Cell Motil Cytoskeleton 46: 166-182.

He Y, Francis F, Myers KA, Yu W, Black MM, Baas PW. 2005. Role of cytoplasmic dynein in the axonal transport of microtubules and neurofilaments. J Cell Biol 168: 697-703.

Herrmann H, Aebi U. 2004. Intermediate filaments: Molecular structure, assembly mechanism, and integration into functionally distinct intracellular Scaffolds. Annu Rev Biochem 73: 749-789.

* Herrmann H, Aebi U. 2016. Intermediate filaments: Structure and assembly. Cold Spring Harb Perspect Biol doi: 101101/cshperspect .a018242.

Herrmann H, Bar H, Kreplak L, Strelkov SV, Aebi U. 2007. Intermediate filaments: From cell architecture to nanomechanics. Nat Rev Mol Cell Biol 8: 562-573.

Hirokawa N. 1982. Cross-linker system between neurofilaments, microtubules, and membranous organelles in frog axons revealed by the quick-freeze, deep-etching method. J Cell Biol 94: 129-142.

Hirokawa N. 1993. Axonal transport and the cytoskeleton. Curr Opin Neurobiol 3: 724-731.

Hirokawa N, Glicksman MA, Willard MB. 1984. Organization of mammalian neurofilament polypeptides within the neuronal cytoskeleton. J Cell Biol 98: 1523-1536.

Hirokawa N, Terada S, Funakoshi T, Tekeda S. 1997. Slow axonal transport: The subunit transport model. Trends Cell Biol 7: 384-388.

Hirokawa N, Niwa S, Tanaka Y. 2010. Molecular motors in neurons: Transport mechanisms and roles in brain function, development, and disease. Neuron 68: 610-638.

Hisanaga S, Hirokawa N. 1988. Structure of the peripheral domains of neurofilaments revealed by low angle rotary shadowing. J Mol Biol 202: 297-305.
Hisanaga S, Hirokawa N. 1990. Dephosphorylation-induced interactions of neurofilaments with microtubules. J Biol Chem 265: 21852-21858.

Hoffman PN, Cleveland DW. 1988. Neurofilament and tubulin expression recapitulates the developmental program during axonal regeneration: Induction of a specific $\beta$-tubulin isotype. Proc Natl Acad Sci 85: $4530-4533$.

Hoffman PN, Lasek RJ. 1975. The slow component of axonal transport. Identification of major structural polypeptides of the axon and their generality among mammalian neurons. J Cell Biol 66: 351-366.

Hoffman PN, Griffin JW, Price DL. 1984. Control of axonal caliber by neurofilament transport. J Cell Biol 99: 705-714.

Hoffman PN, Griffin JW, Gold BG, Price DL. 1985. Slowing of neurofilament transport and the radial growth of developing nerve fibers. $J$ Neurosci 5: 2920-2929.

Hoffman PN, Lopata MA, Watson DF, Luduena RF. 1992. Axonal transport of class II and III $\beta$-tubulin: Evidence that the slow component wave represents the movement of only a small fraction of the tubulin in mature motor axons. J Cell Biol 119: 595-604.

Hoffman PN, Pollock SC, Striph GG. 1993. Altered gene expression after optic nerve transection: Reduced neurofilament expression as a general response to axonal injury. Exp Neurol 119: 32-36.

Hollenbeck PJ, Bray D. 1987. Rapidly transported organelles containing membrane and cytoskeletal components: Their relation to axonal growth. J Cell Biol 105: 2827-2835.

Hsieh ST, Kidd GJ, Crawford TO, Xu Z, Lin WM, Trapp BD, Cleveland DW, Griffin JW. 1994. Regional modulation of neurofilament organization by myelination in normal axons. J Neurosci 14: 6392-6401.

Ishikawa H, Bischoff R, Holtzer H. 1968. Mitosis and intermediate-sized filaments in developing skeletal muscle. J Cell Biol 38: 538-555.

Jacomy H, Zhu Q, Couillard-Despres S, Beaulieu JM, Julien JP. 1999. Disruption of type IV intermediate filament network in mice lacking the neurofilament medium and heavy subunits. J Neurochem 73: 972984.

Jin LQ, Zhang G, Pennicooke B, Laramore C, Selzer ME. 2011. Multiple neurofilament subunits are present in lamprey CNS. Brain Res 1370: $16-33$.

Jordanova A, De Jonghe P, Boerkoel CF, Takashima H, De Vriendt E, Ceuterick C, Martin JJ, Butler IJ, Mancias P, Papasozomenos S, et al. 2003. Mutations in the neurofilament light chain gene (NEFL) cause early onset severe Charcot-Marie-Tooth disease. Brain 126: 590597.

Julien JP, Mushynski WE. 1983. The distribution of phosphorylation sites among identified proteolytic fragments of mammalian neurofilaments. J Biol Chem 258: 4019-4025.

Jung C, Yabe JT, Lee S, Shea TB. 2000a. Hypophosphorylated neurofilament subunits undergo axonal transport more rapidly than more extensively phosphorylated subunits in situ. Cell Motil Cytoskeleton 47: $120-129$.

Jung C, Yabe JT, Shea TB. 2000b. C-terminal phosphorylation of the high molecular weight neurofilament subunit correlates with decreased neurofilament axonal transport velocity. Brain Res 856: 12-19.

Jung C, Chylinski TM, Pimenta A, Ortiz D, Shea TB. 2004. Neurofilament transport is dependent on actin and myosin. J Neurosci 24: 9486-9496.

Jung C, Lee S, Ortiz D, Zhu Q, Julien JP, Shea TB. 2005. The high and middle molecular weight neurofilament subunits regulate the association of neurofilaments with kinesin: Inhibition by phosphorylation of the high molecular weight subunit. Brain Res Mol Brain Res 141: $151-155$.

Kesavapany S, Li BS, Pant HC. 2003. Cyclin-dependent kinase 5 in neurofilament function and regulation. Neurosignals 12: 252-264.

Kim OJ, Ariano MA, Lazzarini RA, Levine MS, Sibley DR. 2002. Neurofilament-M interacts with the D1 dopamine receptor to regulate cell surface expression and desensitization. J Neurosci 22: 5920-5930.

Kim SK, Kim H, Yang YR, Suh PG, Chang JS. 2011. Phosphatidylinositol phosphates directly bind to neurofilament light chain (NF-L) for the regulation of NF-L self assembly. Exp Mol Med 43: 153-160. 
Kornreich M, Malka-Gibor E, Laser-Azogui A, Doron O, Herrmann H, Beck R. 2015. Composite bottlebrush mechanics: $\alpha$-internexin finetunes neurofilament network properties. Soft Matter 11: 5839-5849.

Kriz J, Zhu Q, Julien JP, Padjen AL. 2000. Electrophysiological properties of axons in mice lacking neurofilament subunit genes: Disparity between conduction velocity and axon diameter in absence of NF-H. Brain Res 885: 32-44.

Kuhle J, Gaiottino J, Leppert D, Petzold A, Bestwick JP, Malaspina A, Lu CH, Dobson R, Disanto G, Norgren N, et al. 2015. Serum neurofilament light chain is a biomarker of human spinal cord injury severity and outcome. J Neurol Neurosurg Psychiatry 86: 273-279.

Kural C, Kim H, Syed S, Goshima G, Gelfand VI, Selvin PR. 2005. Kinesin and dynein move a peroxisome in vivo: A tug-of-war or coordinated movement? Science 308: 1469-1472.

Lasek RJ. 1986. Polymer sliding in axons. J Cell Sci Suppl 5: 161-179.

Lavedan C, Buchholtz S, Nussbaum RL, Albin RL, Polymeropoulos MH. 2002. A mutation in the human neurofilament M gene in Parkinson's disease that suggests a role for the cytoskeleton in neuronal degeneration. Neurosci Lett 322: 57-61.

Lee MK, Marszalek JR, Cleveland DW. 1994. A mutant neurofilament subunit causes massive, selective motor neuron death: Implications for the pathogenesis of human motor neuron disease. Neuron 13: 975-988.

Leermakers FA, Zhulina EB. 2010. How the projection domains of NF-L and $\alpha$-internexin determine the conformations of NF-M and NF-H in neurofilaments. Eur Biophys J 39: 1323-1334.

Leterrier JF, Liem RK, Shelanski ML. 1982. Interactions between neurofilaments and microtubule-associated proteins: A possible mechanism for intraorganellar bridging. J Cell Biol 95: 982-986.

Leung CL, He CZ, Kaufmann P, Chin SS, Naini A, Liem RK, Mitsumoto H, Hays AR. 2004. A pathogenic peripherin gene mutation in a patient with amyotrophic lateral sclerosis. Brain Pathol 14: 290-296.

Lewis SE, Nixon RA. 1988. Multiple phosphorylated variants of the high molecular mass subunit of neurofilaments in axons of retinal cell neurons: Characterization and evidence for their differential association with stationary and moving neurofilaments. J Cell Biol 107: 26892701.

Li Y, Jung P, Brown A. 2012. Axonal transport of neurofilaments: A single population of intermittently moving polymers. J Neurosci 32: 746758.

Liem RK, Hutchison SB. 1982. Purification of individual components of the neurofilament triplet: Filament assembly from the 70000 -dalton subunit. Biochemistry 21: 3221-3226.

Liem RK, Yen SH, Salomon GD, Shelanski ML. 1978. Intermediate filaments in nervous tissues. J Cell Biol 79: 637-645.

Llorens J. 2013. Toxic neurofilamentous axonopathies-Accumulation of neurofilaments and axonal degeneration. J Intern Med 273: 478489.

Lunn MP, Crawford TO, Hughes RA, Griffin JW, Sheikh KA. 2002. Antimyelin-associated glycoprotein antibodies alter neurofilament spacing. Brain 125: 904-911.

Ma D, Himes BT, Shea TB, Fischer I. 2000. Axonal transport of microtubule-associated protein 1B (MAP1B) in the sciatic nerve of adult rat: Distinct transport rates of different isoforms. J Neurosci 20: 21122120.

Mahammad S, Murthy SN, Didonna A, Grin B, Israeli E, Perrot R, Bomont P, Julien JP, Kuczmarski E, Opal P, et al. 2013. Giant axonal neuropathy-associated gigaxonin mutations impair intermediate filament protein degradation. J Clin Invest 123: 1964-1975.

Marszalek JR, Williamson TL, Lee MK, Xu Z, Hoffman PN, Becher MW, Crawford TO, Cleveland DW. 1996. Neurofilament subunit NF-H modulates axonal diameter by selectively slowing neurofilament transport. J Cell Biol 135: 711-724.

Matus A, Pehling G, Ackermann M, Maeder J. 1980. Brain postsynaptic densities: The relationship to glial and neuronal filaments. J Cell Biol 87: $346-359$.
McKnight GS. 1991. Cyclic AMP second messenger systems. Curr Opin Cell Biol 3: 213-217.

Menzies FM, Grierson AJ, Cookson MR, Heath PR, Tomkins J, Figlewicz DA, Ince PG, Shaw PJ. 2002. Selective loss of neurofilament expression in $\mathrm{Cu} / \mathrm{Zn}$ superoxide dismutase (SOD1) linked amyotrophic lateral sclerosis. J Neurochem 82: 1118-1128.

Mersiyanova IV, Perepelov AV, Polyakov AV, Sitnikov VF, Dadali EL, Oparin RB, Petrin AN, Evgrafov OV. 2000. A new variant of CharcotMarie-Tooth disease type 2 is probably the result of a mutation in the neurofilament-light gene. Am J Hum Genet 67: 37-46.

Miao L, Teng J, Lin J, Liao X, Chen J. 2013. 14-3-3 proteins interact with neurofilament protein- $\mathrm{L}$ and regulate dynamic assembly of neurofilaments. J Cell Sci 126: 427-436.

Michalczyk K, Ziman M. 2005. Nestin structure and predicted function in cellular cytoskeletal organisation. Histol Histopathol 20: 665-671.

Miki H, Setou M, Kaneshiro K, Hirokawa N. 2001. All kinesin superfamily protein, KIF, genes in mouse and human. Proc Natl Acad Sci 98: 7004-7011.

Millecamps S, Gowing G, Corti O, Mallet J, Julien JP. 2007. Conditional NF-L transgene expression in mice for in vivo analysis of turnover and transport rate of neurofilaments. J Neurosci 27: 4947-4956.

Mitchell CS, Lee RH. 2009. A quantitative examination of the role of cargo-exerted forces in axonal transport. J Theor Biol 257: 430-437.

Miyasaka H, Okabe S, Ishiguro K, Uchida T, Hirokawa N. 1993. Interaction of the tail domain of high molecular weight subunits of neurofilaments with the $\mathrm{COOH}$-terminal region of tubulin and its regulation by $\tau$ protein kinase II. J Biol Chem 268: 22695-22702.

Miyata Y, Hoshi M, Nishida E, Minami Y, Sakai H. 1986. Binding of microtubule-associated protein 2 and $\tau$ to the intermediate filament reassembled from neurofilament $70-\mathrm{kDa}$ subunit protein. Its regulation by calmodulin. J Biol Chem 261: 13026-13030.

Nakagawa T, Chen J, Zhang Z, Kanai Y, Hirokawa N. 1995. Two distinct functions of the carboxyl-terminal tail domain of NF-M upon neurofilament assembly: Cross-bridge formation and longitudinal elongation of filaments. J Cell Biol 129: 411-429.

Nixon RA. 1998. Dynamic behavior and organization of cytoskeletal proteins in neurons: Reconciling old and new findings. BioEssays 20: 798-807.

Nixon RA, Lewis SE. 1986. Differential turnover of phosphate groups on neurofilament subunits in mammalian neurons in vivo. J Biol Chem 261: $16298-16301$.

Nixon RA, Logvinenko KB. 1986. Multiple fates of newly synthesized neurofilament proteins: Evidence for a stationary neurofilament network distributed nonuniformly along axons of retinal ganglion cell neurons. J Cell Biol 102: 647-659.

Nixon RA, Marotta CA. 1984. Degradation of neurofilament proteins by purified human brain cathepsin D. J Neurochem 43: 507-516.

Nixon RA, Shea TB. 1992. Dynamics of neuronal intermediate filaments: A developmental perspective. Cell Motil Cytoskeleton 22: 81-91.

Nixon RA, Sihag RK. 1991. Neurofilament phosphorylation: A new look at regulation and function. Trends Neurosci 14: 501-506.

Nixon RA, Lewis SE, Marotta CA. 1987. Posttranslational modification of neurofilament proteins by phosphate during axoplasmic transport in retinal ganglion cell neurons. J Neurosci 7: 1145-1158.

Nixon RA, Lewis SE, Mercken M, Sihag RK. 1994a. [32P] orthophosphate and [35S]methionine label separate pools of neurofilaments with markedly different axonal transport kinetics in mouse retinal ganglion cells in vivo. Neurochem Res 19: 1445-1453.

Nixon RA, Paskevich PA, Sihag RK, Thayer CY. 1994b. Phosphorylation on carboxyl terminus domains of neurofilament proteins in retinal ganglion cell neurons in vivo: Influences on regional neurofilament accumulation, interneurofilament spacing, and axon caliber. J Cell Biol 126: $1031-1046$

Ohara O, Gahara Y, Miyake T, Teraoka H, Kitamura T. 1993. Neurofilament deficiency in quail caused by nonsense mutation in neurofilament-L gene. J Cell Biol 121: 387-395. 
Okonkwo DO, Pettus EH, Moroi J, Povlishock JT. 1998. Alteration of the neurofilament sidearm and its relation to neurofilament compaction occurring with traumatic axonal injury. Brain Res 784: 1-6.

Pachter JS, Liem RK. 1984. The differential appearance of neurofilament triplet polypeptides in the developing rat optic nerve. Dev Biol 103: 200-210.

Pachter JS, Liem RK. 1985. $\alpha$-Internexin, a 66-kD intermediate filamentbinding protein from mammalian central nervous tissues. J Cell Biol 101: $1316-1322$

Pant HC. 1988. Dephosphorylation of neurofilament proteins enhances their susceptibility to degradation by calpain. Biochem J 256: 665-668.

Pant HC, Veeranna. 1995. Neurofilament phosphorylation. Biochem Cell Biol 73: 575-592.

Pant HC, Shecket G, Gainer H, Lasek RJ. 1978. Neurofilament protein is phosphorylated in the squid giant axon. J Cell Biol 78: R23-R27.

Parysek LM, Goldman RD. 1987. Characterization of intermediate filaments in PC12 cells. J Neurosci 7: 781-791.

Perez-Olle R, Leung CL, Liem RK. 2002. Effects of Charcot-MarieTooth-linked mutations of the neurofilament light subunit on intermediate filament formation. J Cell Sci 115: 4937-4946.

Perez-Olle R, Lopez-Toledano MA, Goryunov D, Cabrera-Poch N, Stefanis L, Brown K, Liem RK. 2005. Mutations in the neurofilament light gene linked to Charcot-Marie-Tooth disease cause defects in transport. J Neurochem 93: 861-874.

Perrot R, Berges R, Bocquet A, Eyer J. 2008. Review of the multiple aspects of neurofilament functions, and their possible contribution to neurodegeneration. Mol Neurobiol 38: 27-65.

Petzold A, Keir G, Warren J, Fox N, Rossor MN. 2007. A systematic review and meta-analysis of CSF neurofilament protein levels as biomarkers in dementia. Neurodegener Dis 4: 185-194.

Pijnenburg YA, Janssen JC, Schoonenboom NS, Petzold A, Mulder C, Stigbrand T, Norgren N, Heijst H, Hack CE, Scheltens P, et al. 2007. CSF neurofilaments in frontotemporal dementia compared with early onset Alzheimer's disease and controls. Dement Geriatr Cogn Disord 23: 225-230.

Porter KR, Bonneville MA. 1973. Fine structure of cells and tissues, 4th ed., p. 184. Lea and Febiger, Philadelphia.

Portier MM, de Nechaud B, Gros F. 1983. Peripherin, a new member of the intermediate filament protein family. Dev Neurosci 6: 335-344.

Povlishock JT, Marmarou A, McIntosh T, Trojanowski JQ, Moroi J. 1997. Impact acceleration injury in the rat: Evidence for focal axolemmal change and related neurofilament sidearm alteration. J Neuropathol Exp Neurol 56: 347-359.

Prahlad V, Helfand BT, Langford GM, Vale RD, Goldman RD. 2000. Fast transport of neurofilament protein along microtubules in squid axoplasm. J Cell Sci 113: 3939-3946.

Rao MV, Houseweart MK, Williamson TL, Crawford TO, Folmer J, Cleveland DW. 1998. Neurofilament-dependent radial growth of motor axons and axonal organization of neurofilaments does not require the neurofilament heavy subunit $(\mathrm{NF}-\mathrm{H})$ or its phosphorylation. $J$ Cell Biol 143: 171-181.

Rao MV, Engle LJ, Mohan PS, Yuan A, Qiu D, Cataldo A, Hassinger L, Jacobsen S, Lee VM, Andreadis A, et al. 2002a. Myosin Va binding to neurofilaments is essential for correct myosin Va distribution and transport and neurofilament density. J Cell Biol 159: 279-290.

Rao MV, Garcia ML, Miyazaki Y, Gotow T, Yuan A, Mattina S, Ward CM, Calcutt NA, Uchiyama Y, Nixon RA, et al. 2002b. Gene replacement in mice reveals that the heavily phosphorylated tail of neurofilament heavy subunit does not affect axonal caliber or the transit of cargoes in slow axonal transport. J Cell Biol 158: 681-693.

Rao MV, Campbell J, Yuan A, Kumar A, Gotow T, Uchiyama Y, Nixon RA. 2003. The neurofilament middle molecular mass subunit carboxylterminal tail domains is essential for the radial growth and cytoskeletal architecture of axons but not for regulating neurofilament transport rate. J Cell Biol 163: 1021-1031.

Rao MV, Mohan PS, Kumar A, Yuan A, Montagna L, Campbell J, Veeranna, Espreafico EM, Julien JP, Nixon RA. 2011. The myosin Va head domain binds to the neurofilament- $\mathrm{L}$ rod and modulates endoplasmic reticulum (ER) content and distribution within axons. PloS ONE 6: e17087.

Rao MV, Yuan A, Campbell J, Kumar A, Nixon RA. 2012. The C-terminal domains of NF-H and NF-M subunits maintain axonal neurofilament content by blocking turnover of the stationary neurofilament network. PloS ONE 7: e44320.

Roots BI. 1983. Neurofilament accumulation induced in synapses by leupeptin. Science 221: 971-972.

Roy S, Coffee P, Smith G, Liem RK, Brady ST, Black MM. 2000. Neurofilaments are transported rapidly but intermittently in axons: Implications for slow axonal transport. J Neurosci 20: 6849-6861.

Saito T, Shima H, Osawa Y, Nagao M, Hemmings BA, Kishimoto T, Hisanaga S. 1995. Neurofilament-associated protein phosphatase 2A: Its possible role in preserving neurofilaments in filamentous states. Biochemistry 34: 7376-7384.

Sakaguchi T, Okada M, Kitamura T, Kawasaki K. 1993. Reduced diameter and conduction velocity of myelinated fibers in the sciatic nerve of a neurofilament-deficient mutant quail. Neurosci Lett 153: 65-68.

Sanchez I, Hassinger L, Paskevich PA, Shine HD, Nixon RA. 1996. Oligodendroglia regulate the regional expansion of axon caliber and local accumulation of neurofilaments during development independently of myelin formation. J Neurosci 16: 5095-5105.

Sanchez I, Hassinger L, Sihag RK, Cleveland DW, Mohan P, Nixon RA. 2000. Local control of neurofilament accumulation during radial growth of myelinating axons in vivo. Selective role of site-specific phosphorylation. J Cell Biol 151: 1013-1024.

Sasaki T, Gotow T, Shiozaki M, Sakaue F, Saito T, Julien JP, Uchiyama Y, Hisanaga S. 2006. Aggregate formation and phosphorylation of neurofilament-L Pro22 Charcot-Marie-Tooth disease mutants. Hum Mol Genet 15: 943-952.

Scharrel L, Ma R, Schneider R, Julicher F, Diez S. 2014. Multimotor transport in a system of active and inactive kinesin-1 motors. Biophys J 107: 365-372.

Scherling CS, Hall T, Berisha F, Klepac K, Karydas A, Coppola G, Kramer JH, Rabinovici G, Ahlijanian M, Miller BL, et al. 2014. Cerebrospinal fluid neurofilament concentration reflects disease severity in frontotemporal degeneration. Ann Neurol 75: 116-126.

Schlaepfer WW, Bruce J. 1990a. Neurofilament proteins are distributed in a diminishing proximodistal gradient along rat sciatic nerve. J Neurochem 55: 453-460.

Schlaepfer WW, Bruce J. 1990b. Simultaneous up-regulation of neurofilament proteins during the postnatal development of the rat nervous system. J Neurosci Res 25: 39-49.

Schlaepfer WW, Freeman LA. 1978. Neurofilament proteins of rat peripheral nerve and spinal cord. J Cell Biol 78: 653-662.

Schmitt FO, Geren BB. 1950. The fibrous structure of the nerve axon in relation to the localization of 'neurotubules'. J Exp Med 91: 499-504.

Schnapp BJ, Reese TS. 1982. Cytoplasmic structure in rapid-frozen axons. J Cell Biol 94: 667-669.

Shah JV, Flanagan LA, Janmey PA, Leterrier JF. 2000. Bidirectional translocation of neurofilaments along microtubules mediated in part by dynein/dynactin. Mol Biol Cell 11: 3495-3508.

Sharp GA, Shaw G, Weber K. 1982. Immunoelectronmicroscopical localization of the three neurofilament triplet proteins along neurofilaments of cultured dorsal root ganglion neurones. Exp Cell Res 137: 403-413.

Shaw G. 1991. Neurofilament proteins. In The neuronal cytoskeleton (ed. Burgoyne RD), pp. 185-214. Wiley-Liss, New York.

Shaw G, Weber K. 1982. Differential expression of neurofilament triplet proteins in brain development. Nature 298: 277-279.

Shaw G, Yang C, Zhang L, Cook P, Pike B, Hill WD. 2004. Characterization of the bovine neurofilament NF-M protein and cDNA sequence, and identification of in vitro and in vivo calpain cleavage sites. Biochem Biophys Res Commun 325: 619-625.

Shaw G, Yang C, Ellis R, Anderson K, Parker Mickle J, Scheff S, Pike B, Anderson DK, Howland DR. 2005. Hyperphosphorylated neurofila- 
ment NF-H is a serum biomarker of axonal injury. Biochem Biophys Res Commun 336: 1268-1277.

Shelanski ML, Albert S, DeVries GH, Norton WT. 1971. Isolation of filaments from brain. Science 174: 1242-1245.

Sherman DL, Krols M, Wu LM, Grove M, Nave KA, Gangloff YG, Brophy PJ. 2012. Arrest of myelination and reduced axon growth when Schwann cells lack mTOR. J Neurosci 32: 1817-1825.

Shetty KT, Link WT, Pant HC. 1993. cdc2-like kinase from rat spinal cord specifically phosphorylates KSPXK motifs in neurofilament proteins: Isolation and characterization. Proc Natl Acad Sci 90: 6844-6848.

Sihag RK, Nixon RA. 1991. Identification of Ser-55 as a major protein kinase A phosphorylation site on the $70-\mathrm{kDa}$ subunit of neurofilaments. Early turnover during axonal transport. J Biol Chem 266: $18861-18867$.

Sihag RK, Jaffe H, Nixon RA, Rong X. 1999. Serine-23 is a major protein kinase A phosphorylation site on the amino-terminal head domain of the middle molecular mass subunit of neurofilament proteins. J Neurochem 72: 491-499.

Sihag RK, Inagaki M, Yamaguchi T, Shea TB, Pant HC. 2007. Role of phosphorylation on the structural dynamics and function of types III and IV intermediate filaments. Exp Cell Res 313: 2098-2109.

Sjogren M, Blomberg M, Jonsson M, Wahlund LO, Edman A, Lind K, Rosengren L, Blennow K, Wallin A. 2001. Neurofilament protein in cerebrospinal fluid: A marker of white matter changes. J Neurosci Res 66: $510-516$.

Song F, Zhang Q, Kou R, Zou C, Gao Y, Xie K. 2012. 2,5-hexanedione altered the degradation of low-molecular-weight neurofilament in rat nerve tissues. Food Chem Toxicol 50: 4277-4284.

Spacek J. 2004. Atlas of ultrastructural neurocytology. http://synapseweb .clm.utexas.edu/atlas.

Steiner JP, Ling E, Bennett V. 1987. Nearest neighbor analysis for brain synapsin I. Evidence from in vitro reassociation assays for association with membrane protein(s) and the $\mathrm{Mr}=68,000$ neurofilament subunit. J Biol Chem 262: 905-914.

Steinert PM, Roop DR. 1988. Molecular and cellular biology of intermediate filaments. Annu Rev Biochem 57: 593-625.

Steinert PM, Chou YH, Prahlad V, Parry DA, Marekov LN, Wu KC, Jang SI, Goldman RD. 1999. A high molecular weight intermediate filament-associated protein in BHK-21 cells is nestin, a type VI intermediate filament protein. Limited co-assembly in vitro to form heteropolymers with type III vimentin and type IV $\alpha$-internexin. J Biol Chem 274: 9881-9890.

Strack S, Westphal RS, Colbran RJ, Ebner FF, Wadzinski BE. 1997. Protein serine/threonine phosphatase 1 and $2 \mathrm{~A}$ associate with and dephosphorylate neurofilaments. Brain Res Mol Brain Res 49: 15-28.

Straube-West K, Loomis PA, Opal P, Goldman RD. 1996. Alterations in neural intermediate filament organization: Functional implications and the induction of pathological changes related to motor neuron disease. J Cell Sci 109: 2319-2329.

Styers ML, Salazar G, Love R, Peden AA, Kowalczyk AP, Faundez V. 2004. The endo-lysosomal sorting machinery interacts with the intermediate filament cytoskeleton. Mol Biol Cell 15: 5369-5382.

Sunil N, Lee S, Shea TB. 2012. Interference with kinesin-based anterograde neurofilament axonal transport increases neurofilament-neurofilament bundling. Cytoskeleton 69: 371-379.

Suzuki H, Takeda M, Nakamura Y, Kato Y, Tada K, Hariguchi S, Nishimura T. 1988. Neurofilament degradation by bovine brain cathepsin D. Neurosci Lett 89: 240-245.

Svitkina TM, Verkhovsky AB, Borisy GG. 1996. Plectin sidearms mediate interaction of intermediate filaments with microtubules and other components of the cytoskeleton. J Cell Biol 135: 991-1007.

Teunissen CE, Khalil M. 2012. Neurofilaments as biomarkers in multiple sclerosis. Mult Scler 18: 552-556.

Tomkins J, Usher P, Slade JY, Ince PG, Curtis A, Bushby K, Shaw PJ. 1998. Novel insertion in the KSP region of the neurofilament heavy gene in amyotrophic lateral sclerosis (ALS). Neuroreport 9: 3967-3970.
Toyoshima I, Kato K, Sugawara M, Wada C, Okawa S, Kobayashi M, Masamune O, Watanabe S. 2000. Massive accumulation of M and $\mathrm{H}$ subunits of neurofilament proteins in spinal motor neurons of neurofilament deficient Japanese quail, Quv. Neurosci Lett 287: $175-178$.

Trivedi N, Jung P, Brown A. 2007. Neurofilaments switch between distinct mobile and stationary states during their transport along axons. $J$ Neurosci 27: 507-516.

Uchida A, Alami NH, Brown A. 2009. Tight functional coupling of kinesin-1A and dynein motors in the bidirectional transport of neurofilaments. Mol Biol Cell 20: 4997-5006.

Uchida A, Colakoglu G, Wang L, Monsma PC, Brown A. 2013. Severing and end-to-end annealing of neurofilaments in neurons. Proc Natl Acad Sci 110: E2696-E2705.

Undamatla J, Szaro BG. 2001. Differential expression and localization of neuronal intermediate filament proteins within newly developing neurites in dissociated cultures of Xenopus laevis embryonic spinal cord. Cell Motil Cytoskeleton 49: 16-32.

Veeranna, Shetty KT, Link WT, Jaffe H, Wang J, Pant HC. 1995. Neuronal cyclin-dependent kinase- 5 phosphorylation sites in neurofilament protein $(\mathrm{NF}-\mathrm{H})$ are dephosphorylated by protein phosphatase $2 \mathrm{~A}$. J Neurochem 64: 2681-2690.

Veeranna, Amin ND, Ahn NG, Jaffe H, Winters CA, Grant P, Pant HC. 1998. Mitogen-activated protein kinases (Erk1,2) phosphorylate LysSer-Pro (KSP) repeats in neurofilament proteins NF-H and NF-M. J Neurosci 18: 4008-4021.

Veeranna, Yang DS, Lee JH, Vinod KY, Stavrides P, Amin ND, Pant HC, Nixon RA. 2011. Declining phosphatases underlie aging-related hyperphosphorylation of neurofilaments. Neurobiol Aging 32: 20162029.

Wagner OI, Lifshitz J, Janmey PA, Linden M, McIntosh TK, Leterrier JF. 2003. Mechanisms of mitochondria-neurofilament interactions. J Neurosci 23: 9046-9058.

Wagner OI, Ascano J, Tokito M, Leterrier JF, Janmey PA, Holzbaur EL. 2004. The interaction of neurofilaments with the microtubule motor cytoplasmic dynein. Mol Biol Cell 15: 5092-5100.

Wang L, Brown A. 2010. A hereditary spastic paraplegia mutation in kinesin-1A/KIF5A disrupts neurofilament transport. Mol Neurodegener 5: 52.

Wang L, Ho CL, Sun D, Liem RK, Brown A. 2000. Rapid movement of axonal neurofilaments interrupted by prolonged pauses. Nat Cell Biol 2: $137-141$.

Wang Y, Wang Q, Wang J. 2002. [Detection of level and mutation of neurofilament mRNA in Alzheimer's disease]. Zhonghua Yi Xue Za Zhi 82: 519-522.

Wang Z, Edwards JG, Riley N, Provance DW Jr, Karcher R, Li XD, Davison IG, Ikebe M, Mercer JA, Kauer JA, et al. 2008. Myosin Vb mobilizes recycling endosomes and AMPA receptors for postsynaptic plasticity. Cell 135: 535-548.

Willard M, Simon C. 1981. Antibody decoration of neurofilaments. J Cell Biol 89: 198-205.

Willard M, Simon C. 1983. Modulations of neurofilament axonal transport during the development of rabbit retinal ganglion cells. Cell 35: 551-559.

Wong TH, Chiu WZ, Breedveld GJ, Li KW, Verkerk AJ, Hondius D, Hukema RK, Seelaar H, Frick P, Severijnen LA, et al. 2014. PRKAR1B mutation associated with a new neurodegenerative disorder with unique pathology. Brain 137: 1361-1373.

Xia CH, Roberts EA, Her LS, Liu X, Williams DS, Cleveland DW, Goldstein LS. 2003. Abnormal neurofilament transport caused by targeted disruption of neuronal kinesin heavy chain KIF5A. J Cell Biol 161: 5566.

Xu Z, Cork LC, Griffin JW, Cleveland DW. 1993. Increased expression of neurofilament subunit NF-L produces morphological alterations that resemble the pathology of human motor neuron disease. Cell 73: 2333. 
A. Yuan et al.

Yabe JT, Pimenta A, Shea TB. 1999. Kinesin-mediated transport of neurofilament protein oligomers in growing axons. J Cell Sci 112: 37993814.

Yabe JT, Jung C, Chan WK, Shea TB. 2000. Phospho-dependent association of neurofilament proteins with kinesin in situ. Cell Motil Cytoskeleton 45: 249-262.

Yamasaki H, Itakura C, Mizutani M. 1991. Hereditary hypotrophic axonopathy with neurofilament deficiency in a mutant strain of the Japanese quail. Acta Neuropathol 82: 427-434.

Yang Y, Dowling J, Yu QC, Kouklis P, Cleveland DW, Fuchs E. 1996. An essential cytoskeletal linker protein connecting actin microfilaments to intermediate filaments. Cell 86: 655-665.

Yang Y, Bauer C, Strasser G, Wollman R, Julien JP, Fuchs E. 1999. Integrators of the cytoskeleton that stabilize microtubules. Cell 98: 229238 .

Yoshihara T, Yamamoto M, Hattori N, Misu K, Mori K, Koike H, Sobue G. 2002. Identification of novel sequence variants in the neurofilament-light gene in a Japanese population: Analysis of Charcot-Marie-Tooth disease patients and normal individuals. J Peripher Nerv Syst 7: 221-224.

Yuan A. 1997. "Axonal transport of cytoskeletal and associated proteins". $\mathrm{PhD}$ thesis, Otago University, Dunedin, New Zealand.

Yuan A, Rao MV, Kumar A, Julien JP, Nixon RA. 2003. Neurofilament transport in vivo minimally requires hetero-oligomer formation. $J$ Neurosci 23: 9452-9458.

Yuan A, Nixon RA, Rao MV. 2006a. Deleting the phosphorylated tail domain of the neurofilament heavy subunit does not alter neurofilament transport rate in vivo. Neurosci Lett 393: 264-268.

Yuan A, Rao MV, Sasaki T, Chen Y, Kumar A, Veeranna, Liem RK, Eyer J, Peterson AC, Julien JP, et al. 2006b. $\alpha$-internexin is structurally and functionally associated with the neurofilament triplet proteins in the mature CNS. J Neurosci 26: 10006-10019.

Yuan A, Sasaki T, Rao MV, Kumar A, Kanumuri V, Dunlop DS, Liem RK, Nixon RA. 2009. Neurofilaments form a highly stable stationary cytoskeleton after reaching a critical level in axons. J Neurosci 29: 1131611329.

Yuan A, Rao MV, Veeranna, Nixon RA. 2012a. Neurofilaments at a glance. J Cell Sci 125: 3257-3263.

Yuan A, Sasaki T, Kumar A, Peterhoff CM, Rao MV, Liem RK, Julien JP, Nixon RA. 2012b. Peripherin is a subunit of peripheral nerve neurofilaments: Implications for differential vulnerability of CNS and peripheral nervous system axons. J Neurosci 32: 8501-8508.

Yuan A, Hassinger L, Rao MV, Julien JP, Miller CC, Nixon RA. 2015a. Dissociation of axonal neurofilament content from its transport rate. PloS ONE 10: $\mathrm{e} 0133848$.
Yuan A, Sershen H, Veeranna, Basavarajappa BS, Kumar A, Hashim A, Berg M, Lee JH, Sato Y, Rao MV, et al. 2015b. Functions of neurofilaments in synapses. Mol Psychiatry 20: 915.

Yuan A, Sershen H, Veeranna, Basavarajappa BS, Kumar A, Hashim A, Berg M, Lee JH, Sato Y, Rao MV, et al. 2015c. Neurofilament subunits are integral components of synapses and modulate neurotransmission and behavior in vivo. Mol Psychiatry 20: 986-994.

Yum SW, Zhang J, Mo K, Li J, Scherer SS. 2009. A novel recessive Nefl mutation causes a severe, early-onset axonal neuropathy. Ann Neurol 66: $759-770$.

Zala D, Hinckelmann MV, Yu H, Lyra da Cunha MM, Liot G, Cordelieres FP, Marco S, Saudou F. 2013. Vesicular glycolysis provides on-board energy for fast axonal transport. Cell 152: 479-491.

Zetterberg H, Skillback T, Mattsson N, Trojanowski JQ, Portelius E, Shaw LM, Weiner MW, Blennow K, Alzheimer's Disease Neuroimaging. 2016. Association of cerebrospinal fluid neurofilament light concentration with Alzheimer disease progression. JAMA Neurology 73: 6067.

Zhang B, Tu P, Abtahian F, Trojanowski JQ, Lee VM. 1997. Neurofilaments and orthograde transport are reduced in ventral root axons of transgenic mice that express human SOD1 with a G93A mutation. J Cell Biol 139: 1307-1315.

Zhao Y, Szaro BG. 1995. The optic tract and tectal ablation influence the composition of neurofilaments in regenerating optic axons of Xenopus laevis. J Neurosci 15: 4629-4640.

Zheng YL, Li BS, Veeranna, Pant HC. 2003. Phosphorylation of the head domain of neurofilament protein (NF-M): A factor regulating topographic phosphorylation of NF-M tail domain KSP sites in neurons. J Biol Chem 278: 24026-24032.

Zhu Q, Couillard-Despres S, Julien JP. 1997. Delayed maturation of regenerating myelinated axons in mice lacking neurofilaments. Exp Neurol 148: 299-316.

Zhu Q, Lindenbaum M, Levavasseur F, Jacomy H, Julien JP. 1998. Disruption of the NF-H gene increases axonal microtubule content and velocity of neurofilament transport: Relief of axonopathy resulting from the toxin $\beta, \beta^{\prime}$-iminodipropionitrile. J Cell Biol 143: 183-193.

Zhu X, Liu Y, Yin Y, Shao A, Zhang B, Kim S, Zhou J. 2009. MSC p43 required for axonal development in motor neurons. Proc Natl Acad Sci 106: $15944-15949$.

Zuchner S, Vorgerd M, Sindern E, Schroder JM. 2004. The novel neurofilament light (NEFL) mutation Glu397Lys is associated with a clinically and morphologically heterogeneous type of Charcot-MarieTooth neuropathy. Neuromuscul Disord 14: 147-157. 


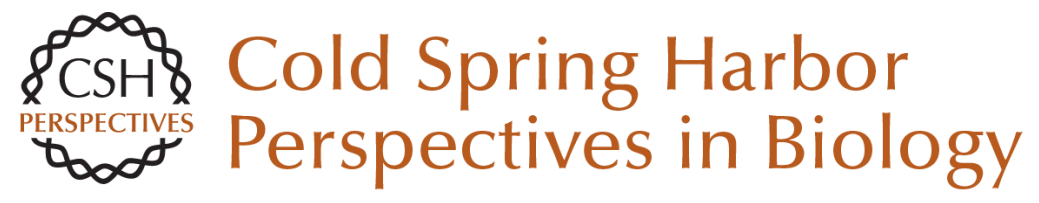

\section{Neurofilaments and Neurofilament Proteins in Health and Disease}

Aidong Yuan, Mala V. Rao, Veeranna and Ralph A. Nixon

Cold Spring Harb Perspect Biol 2017; doi: 10.1101/cshperspect.a018309

Subject Collection The Cytoskeleton

Microtubules and Microtubule-Associated

Proteins

Holly V. Goodson and Erin M. Jonasson

Motor Proteins

H. Lee Sweeney and Erika L.F. Holzbaur

Myosin-Driven Intracellular Transport Margaret $A$. Titus

The Actin Cytoskeleton and Actin-Based Motility Tatyana Svitkina

\section{Mechanical Properties of the Cytoskeleton and Cells \\ Adrian F. Pegoraro, Paul Janmey and David A.} Weitz

Intermediate Filaments and the Regulation of Cell Motility during Regeneration and Wound Healing Fang Cheng and John E. Eriksson

Intermediate Filaments and the Plasma Membrane Jonathan C.R. Jones, Chen Yuan Kam, Robert M. Harmon, et al.

Intracellular Motility of Intermediate Filaments Rudolf E. Leube, Marcin Moch and Reinhard Windoffer
Overview of the Cytoskeleton from an

Evolutionary Perspective

Thomas D. Pollard and Robert D. Goldman

Types I and II Keratin Intermediate Filaments Justin T. Jacob, Pierre A. Coulombe, Raymond Kwan, et al.

Muscle Contraction

H. Lee Sweeney and David W. Hammers

Type III Intermediate Filaments Desmin, Glial

Fibrillary Acidic Protein (GFAP), Vimentin, and

Peripherin

Elly M. Hol and Yassemi Capetanaki

Cytokinesis in Metazoa and Fungi Michael Glotzer

Ciliary Motility: Regulation of Axonemal Dynein Motors

Rasagnya Viswanadha, Winfield S. Sale and Mary

E. Porter

Actin-Based Adhesion Modules Mediate Cell Interactions with the Extracellular Matrix and Neighboring Cells

Alexia I. Bachir, Alan Rick Horwitz, W. James Nelson, et al.

Microtubule-Based Transport and the Distribution,

Tethering, and Organization of Organelles Kari Barlan and Vladimir I. Gelfand

For additional articles in this collection, see http://cshperspectives.cshlp.org/cgi/collection/

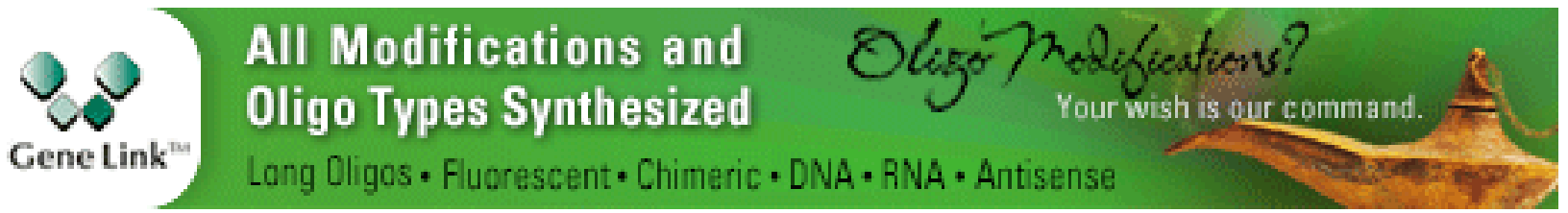

Copyright @ 2017 Cold Spring Harbor Laboratory Press; all rights reserved 
For additional articles in this collection, see http://cshperspectives.cshlp.org/cgi/collection/

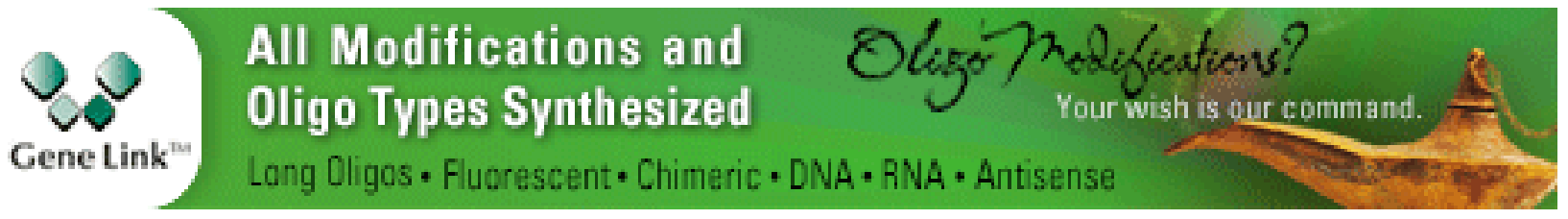

Copyright @ 2017 Cold Spring Harbor Laboratory Press; all rights reserved 